\title{
Challenges in disclosing and receiving a diagnosis of dementia: a systematic review of practice from the perspectives of people with dementia, carers, and healthcare professionals
}

\author{
Jennifer Yates, ${ }^{1}$ (1) Miriam Stanyon, ${ }^{1}$ Rajvinder Samra, ${ }^{2}$ and Linda Clare ${ }^{3}$ \\ ${ }^{1}$ Division of Psychiatry and Applied Psychology, School of Medicine, University of Nottingham, Nottingham, UK \\ ${ }^{2}$ School of Health, Wellbeing and Social Care, The Open University, Milton Keynes, UK \\ ${ }^{3}$ College of Medicine and Health, University of Exeter, Exeter, UK
}

ABSTRACT

Background: Disclosing a diagnosis of dementia is a key process involving people with dementia, carers, and healthcare professionals (HCPs) that can facilitate access to treatment and support. Receiving a diagnosis of dementia may represent a change in identity and loss of a planned-for future, resulting in an emotional impact for both people with dementia and carers. Delivering the diagnosis of dementia can be difficult and draining for HCPs.

Methods: We conducted a systematic review that included studies which explored the experience of giving or receiving a diagnosis of dementia from the perspectives of people with dementia, carers, or HCPs. All study designs were eligible except for previous literature reviews. Findings were analyzed thematically and grouped into categories and then synthesized into a narrative review. The quality of all included studies was assessed.

Results: Fifty-two studies were included in this review. Findings indicated that receiving a diagnosis is generally a negative process for people with dementia, carers, and HCPs and leaves carers in particular feeling uncertain over the prognosis and future of the person they care for. Disclosing a diagnosis of dementia is a difficult and complex process, for which formal training and guidance is lacking. Carers in particular would welcome more opportunity for realistic and hopeful discussions of the implications of receiving a diagnosis of dementia.

Conclusions: Changes in some aspects of disclosure, such as providing a truthful diagnosis to the person with dementia, have occurred over the last decade. A process approach involving pre-diagnostic counseling and follow-up appointments could enable discussions regarding prognosis and the future, create opportunities to clarify the diagnosis, and reduce emotional burden on HCPs. There is a need for more objective evidence that considers the perspectives of all individuals involved.

Key words: dementia, diagnosis, disclosure, carers, healthcare professionals

Receiving a diagnosis of dementia is an important step for people with dementia because it facilitates access to interventions, and potential support from health and social services and third-sector organizations (Robinson et al., 2015). Receiving a diagnosis may be an emotionally charged experience, representing a transition in identity for people with dementia and their carers requiring an emotional readjustment and reappraisal of their future (Robinson et al., 2011).

Correspondence should be addressed to: Jennifer Yates, C22, Institute of Mental Health, Jubilee Campus, University of Nottingham, Nottingham, NG7 2TU, UK, Phone: 0115 8230410. E-mail: jennifer.yates@nottingham.ac.uk. Received 27 May 2020; revision requested 17 Jul 2020; revised version received 12 Dec 2020; accepted 14 Jan 2021. First published online 17 March 2021.
The proportion of those developing symptoms of dementia who receive a diagnosis has increased in the UK (Abhayaratne et al., 2019) and internationally (World Health Organization, 2020), partly in response to policy changes (Department of Health, 2015), and due to greater awareness and acceptance of dementia. A recent systematic review (van den Dungen et al., 2014) using a pooled average based on 9,065 respondents from 23 studies demonstrated that approximately $85 \%$ of people with cognitive impairment would wish to be told a diagnosis if one were made. Knowledge of prognosis and illness trajectories enables people to plan and ensure their affairs are in order or undertake lifestyle changes (Woods et al., 2019). Typically, in developed 
countries, diagnosis disclosure occurs in secondary care settings, conducted by professionals such as psychiatrists, clinical psychologists, or specialist nurses. However, some diagnosis disclosures occur in primary care, delivered by a primary care physician (PCP). The time from developing awareness of cognitive changes to receiving a diagnosis varies across individuals, but can be a lengthy process; a delay of 3 years is not uncommon (Chrisp et al., 2011). The communication and delivery of the diagnosis require careful management to account for a variety of reactions, needs, and levels of understanding from both the person with dementia and carers accompanying them to the disclosure meeting (Bunn et al., 2012).

There are differences between healthcare professionals' (HCPs) perceptions of best practice when disclosing a diagnosis of dementia and the perceptions of people with dementia or carers, which raises ethical dilemmas about how to respect these different needs (Dooley et al., 2015). An earlier literature review (Lecouturier et al., 2008) identified a list of best practice behaviors and combined this with a qualitative exploration and consensus approach to identify eight categories of best practice for disclosure. These categories comprised preparing for disclosure, integrating family members, exploring the patient's perspectives, disclosing the diagnosis, responding to the patient's reactions, focusing on quality of life (QoL) and well-being, planning for the future, and communicating effectively. While comprehensive, this review is now over 10 years old and the authors did not critically appraise the included research. Another review (Werner et al., 2013) covering a similar topic and time frame addressed a broad range of topics related to dementia diagnosis disclosure, but without a specific focus on which practices are typical and how they might be perceived. Given the recent policy initiatives around early diagnosis and changes in societal awareness of dementia over the last decade (Department of Health, 2015), an updated review of the evidence regarding disclosure from the perspectives of people with dementia, carers, and HCPs is required.

\section{Objectives}

This review aimed to explore the experiences of giving or receiving a diagnosis of dementia. It identified common disclosure practices, challenges associated with disclosing the diagnosis, and needs of different individuals involved in the disclosure. It extended earlier work by including a systematic search strategy and a critical appraisal of the results using an established quality assessment tool and went beyond describing the range of possible practices and behavior to identify what is reported as typically occurring in practice and how this is perceived.

\section{Methods}

\section{Search strategy}

A search of the PubMed, CINAHL, and Web of Science databases was conducted on 31 October 2018; updated on 7 February 2020. Reference sections of included papers were hand-searched to identify further publications. The terms "dementia" AND "diagnosi*" were used to search titles and abstracts. A second search was conducted which combined these with the terms "disclosure" OR "best practice," used to search in all fields. The study flowchart is shown in Figure 1. Due to the large number of studies conducted on this topic, the search was restricted to the last 10 years (2008 onward).

\section{Study selection}

Studies were included if they were written in English and provided information on delivering or receiving a diagnosis of dementia. All study types were eligible except for papers that only included a review of previous literature. Studies from the perspectives of HCPs, patients, and carers were all considered. The two primary reviewers (JY and MS) screened the titles, excluding papers that were not relevant, and then reviewed the abstracts. Full texts were retrieved if the title and abstract suggested that an aspect of delivering or receiving a diagnosis of dementia was explored. JY and MS conducted this task jointly, resolving differences in judgment through discussion and agreement.

\section{Data collection and synthesis}

Data were extracted using a table developed by JY and MS to capture the study details (Table 1). Initially, JY and MS extracted the data together to ensure consistency, before continuing to extract data independently and amalgamating tables once complete. As data were extracted, a number of similar ideas and issues were identified in the findings. These were collated in a separate document and added to by JY and MS until data extraction was complete. Similar findings were grouped to form thematic categories. These themes were refined and amalgamated where possible through discussion and during the writing of the narrative by the whole research team. Themes were reported in a narrative format.

\section{Quality review}

Methodological quality was assessed by JY and MS using the Joanna Briggs Institute (JBI) checklists (Aromataris and Munn, 2017). The corresponding 


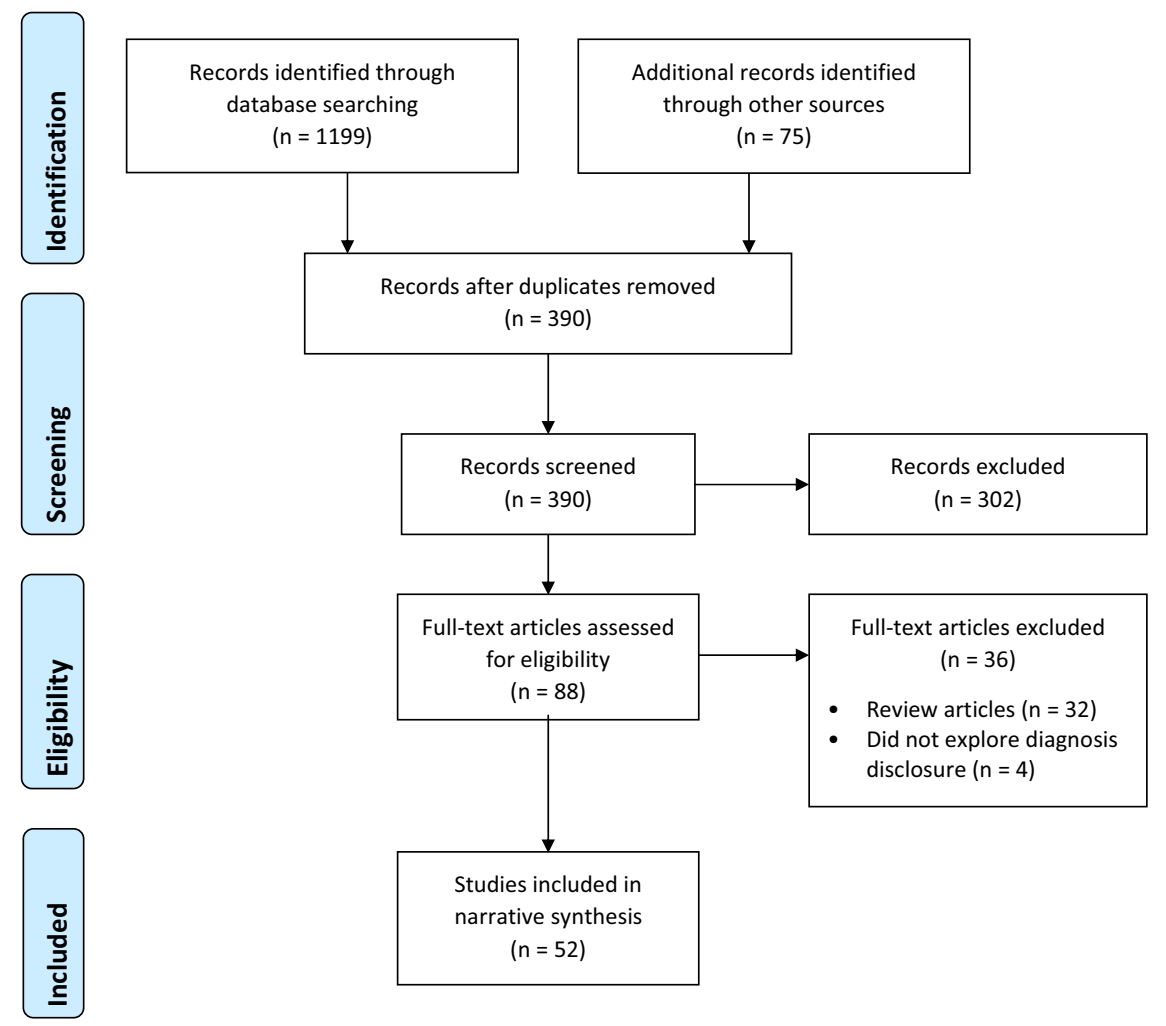

Figure 1. PRISMA flow diagram of included studies.

checklists for each study design were used. A rating of methodological quality that was comparable across different designs was made by calculating the number of items endorsed on each checklist for each paper and converting this into a percentage. Ten percent of the papers were sampled using a random number generator and assessed for quality by a third reviewer (AH). Reviewer scores were compared for consistency using a paired samples t-test. No significant differences were found $(t(4)=2.33, p=.080)$, suggesting a robust quality assessment.

\section{Results}

Fifty-two studies were included. Main findings are summarized in Table 1. Findings are categorized under the following themes: content of the diagnosis disclosure; emotional impact; communication of the diagnosis; people involved; attitudes toward diagnosis disclosure; use of diagnostic tests and assessments; truth telling and deception; timeliness; and training and skills.

\section{Quality assessment}

Quality assessment scores are shown in Table 1. Detailed assessments can be obtained on request. The scores represent the percentage of items on each study design-specific checklist endorsed, and higher percentages reflect higher quality. Scores ranged from $60 \%$ to $100 \%$, and of the 52 studies, 13 scored $100 \%$, seven scored $90-100 \%, 14$ scored $80-90 \%$, 12 scored $70-80 \%$, and six scored $60-70 \%$. Studies scoring lower tended to have qualitative designs. The most frequent quality issues included a failure to specify the underpinning philosophy of the research approach, so the congruence between the philosophical perspective and the research methodology was unknown, and a lack of reflexivity to locate the researcher culturally and theoretically, acknowledging the impact of the researcher on the research and vice versa. Studies scoring higher tended to utilize survey designs, consensus methods, and observations.

\section{Study design types}

This review included 1 case report, 20 crosssectional studies yielding quantitative data, 5 studies that were opinion pieces, commentaries, or utilized consensus methodologies with experts, 24 qualitative studies, 2 quasi-experimental studies, and 1 randomized controlled trial.

\section{Participant characteristics}

Participants were HCPs, people with dementia, carers, and people who had attended memory assessment services but not received a diagnosis of dementia at the time of participation. Sixteen studies 
Table 1. Main findings and study details of included studies

\begin{tabular}{|c|c|c|c|c|c|c|}
\hline REFERENCE & PARTICIPANTS & SETTING & DESIGN & AIM & MAIN FINDINGS & JBI \% \\
\hline $\begin{array}{l}\text { Abe et al., 2019: } \\
\text { Perspectives on } \\
\text { disclosure of the } \\
\text { dementia diagnosis } \\
\text { among primary } \\
\text { care physicians } \\
\text { (PCP) in Japan: a } \\
\text { qualitatively driven } \\
\text { mixed methods } \\
\text { study }\end{array}$ & 24 PCPs & Japan & $\begin{array}{l}\text { Qualitative semi- } \\
\text { structured inter- } \\
\text { views and a } \\
\text { ranking task. }\end{array}$ & $\begin{array}{l}\text { To investigate how PCPs } \\
\text { in Japan approach dis- } \\
\text { closure of a dementia } \\
\text { diagnosis to patients } \\
\text { and family members. }\end{array}$ & $\begin{array}{l}\text { Diagnoses were disclosed jointly to the person with } \\
\text { dementia and their family members for all participants, } \\
\text { and cooperation and well-being of family members was } \\
\text { important to physicians in maintaining QoL for the } \\
\text { person with dementia. Physicians were concerned about } \\
\text { the potential negative psychological impact on patients, } \\
\text { the degree to which patients understood the information } \\
\text { provided, and the stigma associated with dementia. } \\
\text { Almost half of the sample reported they did not receive } \\
\text { training in disclosing a diagnosis of dementia and were } \\
\text { unsure if their approach was appropriate. }\end{array}$ & $70 \%$ \\
\hline $\begin{array}{l}\text { Bailey et al., 2019: } \\
\text { "How do they want } \\
\text { to know?" Doctors' } \\
\text { perspectives on } \\
\text { making and com- } \\
\text { municating a diag- } \\
\text { nosis of dementia }\end{array}$ & $\begin{array}{l}15 \text { doctors (13 old } \\
\text { age psychiatrists } \\
\text { and } 2 \text { geriatricians) }\end{array}$ & UK & $\begin{array}{l}\text { Qualitative focus } \\
\text { groups. }\end{array}$ & $\begin{array}{l}\text { To investigate the views } \\
\text { and experiences of } \\
\text { doctors making and } \\
\text { delivering diagnoses in } \\
\text { memory clinics. }\end{array}$ & $\begin{array}{l}\text { Organization of some memory clinics involves allied health } \\
\text { professionals conducting assessments, so doctors disclos- } \\
\text { ing the diagnosis can be meeting that patient for the first } \\
\text { time, which feels unnatural and makes it difficult for the } \\
\text { doctor to gauge the patients' readiness and expectations. } \\
\text { The diagnosis was seen as a useful framework to involve } \\
\text { other services and open discussions about possible } \\
\text { therapies. Participants reported managing the different } \\
\text { audiences (patient and companion) in the consultation was } \\
\text { challenging and balancing the needs of both could lead to } \\
\text { conflict. Few participants reported receiving specific } \\
\text { training and most relied on basic principles taught in } \\
\text { medical school, and there was a lack of supervision and } \\
\text { support in discussing the emotional impact on doctors } \\
\text { themselves. Participants tended to use the word dementia } \\
\text { but some approached it gradually by introducing the idea of } \\
\text { memory problems first. There was a tension between } \\
\text { presenting a hopeful picture, while also being honest, and } \\
\text { reflecting that there is uncertainty in the diagnosis. } \\
\text { Participants reflected that due to service pressures there } \\
\text { just wasn't enough time to cover everything they wanted to } \\
\text { in a disclosure meeting and consequently follow-up } \\
\text { appointments are crucial. }\end{array}$ & $70 \%$ \\
\hline $\begin{array}{l}\text { Bennett et al., 2018: } \\
\text { Developing a tool } \\
\text { to support diag- } \\
\text { nostic delivery of } \\
\text { dementia }\end{array}$ & $\begin{array}{l}14 \text { interviews, } 4 \text { clini- } \\
\text { cians, } 4 \text { patients, } \\
5 \text { companions } \\
13 \text { took part in focus } \\
\text { groups, } \\
2 \text { PwD, } 4 \text { companions } \\
7 \text { clinicians }\end{array}$ & $\begin{array}{l}\text { MAS clinics in a } \\
\text { large UK city }\end{array}$ & $\begin{array}{l}\text { Qualitative interviews } \\
\text { with thematic ana- } \\
\text { lysis to produce a } \\
\text { tool for clinicians } \\
\text { evaluated in focus } \\
\text { groups. }\end{array}$ & $\begin{array}{l}\text { To develop a tool specific } \\
\text { to dementia diagnostic } \\
\text { delivery based on clin- } \\
\text { ician, patient, and com- } \\
\text { panion experiences. }\end{array}$ & $\begin{array}{l}\text { Themes: } \\
\text { 1. Overcoming barriers to good delivery. 2. Navigation of } \\
\text { multiple journeys (attendee's emotions and clinician's } \\
\text { emotions). 3. Overt tasks (develop a supporting rela- } \\
\text { tionship, promote consent and choice, develop under- } \\
\text { standing, be patient centered, and provide emotional } \\
\text { support). 4. Covert tasks (overcoming power imbalance }\end{array}$ & $75 \%$ \\
\hline
\end{tabular}




\section{Table 1. Continued}

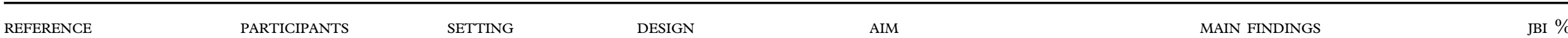

between clinician and patient, continual adaptation,

awareness, and management of dynamics)

Focus groups: patients would like information about the appointment beforehand. Some experienced clinicians may not want a good practice guide.

Bradford et al., 2011: 132 dementia Knowledge of patients and documented de183 caregivers mentia diagnosis and treatment in veterans and their caregivers dyad)
Medical center in Houstan, USA ical records with
icison of med self-reported questionnaire.
Burns et al., 2017: amyloid status in cognitively normal older adults Safety of disclosing
97 cognitively normal University of participants who Kansas larger trial

Disease Center, USA were involved in a Alzheimer's
Part of a larger trial evaluating the effects of exercise on $\mathrm{AD}$ biomarkers. Mood was assessed using validated measures before the scan, at the disclosure visit, 6 weeks and 6 months after disclosure.
To determine the extent to 670 which patients' and caregivers' perceptions of dementia diagnosis and prescribed medications are consistent with information in patients' medical records. And to compare patients' and caregivers' perceptions to one another to explore the extent to which knowledge of dementia diagnosis and treatment is shared within the dyad.

To evaluate safety and tolerability of disclosure of elevated amyloid levels shown on PET scans. whether findings are attributable to participant's factua

There were no differences between the amyloid elevated

Anxiety increased in amyloid elevated participants at a low

Higher levels of anxiety and depression at baseline were

Amyloid-elevated participants did not regret learning the

The authors note that discussion of the scan frames the results

Further, the authors stress using terms "elevated" rather than

Campbell et al.

149 patients with

2008: Dementia,

diagnosis of

3 clinical referral Secondary data diagnostic

\section{sites, USA}

analysis of survey
To investigate the general awareness of cognitive impairment in persons
$\%$ of carers and $24 \%$ of patients were aware of their diagnosis of dementia of some kind. For patients, this may be because of lack of ability to recall. Unclear knowledge or variation in disclosure practices. Patients more likely to recall that they had been prescribed a memory-enhancing drug. Only in $10 \%$ of dyads did both caregiver and patient agree on the dementia diagnosis indicating that interventions should be dyadic. group and the amyloid non-elevated group for depression at any time point. level on the day of disclosure but was not sustained at 6 weeks or 6 months. modestly predictive of levels of anxiety and depression at follow-up. outcome of their scan. conceptually as a risk factor for development of $\mathrm{AD}$ rather than as a diagnostic tool. positive to avoid confusion of positive being beneficial.

$80 \%$

- nine $(26.2 \%)$ participants reported being told by

physician about a diagnosis of dementia or memory

problems. This recall was associated with younger age 
Table 1. Continued

\begin{tabular}{|c|c|c|c|c|c|c|}
\hline REFERENCE & PARTICIPANTS & SETTING & DESIGN & AIM & MAIN FINDINGS & JBI \% \\
\hline $\begin{array}{l}\text { disclosure, and } \\
\text { self-reported } \\
\text { health status }\end{array}$ & & & & $\begin{array}{l}\text { with documented } \\
\text { dementia, evaluate the } \\
\text { subject's recall of a } \\
\text { diagnostic disclosure } \\
\text { from a physician and } \\
\text { their recollection of the } \\
\text { discussion, and deter- } \\
\text { mine whether this } \\
\text { awareness of cognitive } \\
\text { impairment or the recall } \\
\text { of diagnostic disclosure } \\
\text { is associated with } \\
\text { poorer self-rated health } \\
\text { scores. }\end{array}$ & $\begin{array}{l}(\mathrm{p}<.001) \text {, male sex }(\mathrm{p}=.04) \text {, and higher education level } \\
(\mathrm{p}=.02) \text {. African Americans reported poorer self-rated } \\
\text { health scores (odds ratio }(\mathrm{OR}) 52.4,95 \% \text { confidence } \\
\text { interval }(\mathrm{CI}) 51.1-5.1) \text {. } \\
\text { Persons who reported being told by a physician of a } \\
\text { diagnosis of dementia were more likely to report poorer } \\
\text { self-rated health (OR } 2.5,95 \% \text { CI } 1.1-5.5) \text {. }\end{array}$ & \\
\hline $\begin{array}{l}\text { Carpenter et al., } \\
\text { 2008: Reaction to a } \\
\text { dementia diagnosis } \\
\text { in individuals with } \\
\text { AD and mild cog- } \\
\text { nitive impairment } \\
\text { (MCI) }\end{array}$ & $\begin{array}{l}62 \text { participant-com- } \\
\text { panion dyads }\end{array}$ & $\begin{array}{l}\text { Memory and } \\
\text { Aging Project } \\
\text { and the } \\
\text { Alzhiemer's } \\
\text { Disease Re- } \\
\text { search Centre, } \\
\text { (Washington, } \\
\text { USA) }\end{array}$ & $\begin{array}{l}\text { Before and after } \\
\text { diagnosis ques- } \\
\text { tionnaire }\end{array}$ & $\begin{array}{l}\text { To examine the psycho- } \\
\text { logical reaction to } \\
\text { receiving a dementia } \\
\text { diagnosis in individuals } \\
\text { attending an Alzhei- } \\
\text { mer's Disease Research } \\
\text { Centre (ADRC) }\end{array}$ & $\begin{array}{l}\text { Most individuals and their companions seeking a dementia } \\
\text { evaluation do not experience adverse psychological } \\
\text { reactions when they receive diagnostic feedback. Symp- } \\
\text { toms of anxiety and depression remain stable or even } \\
\text { decline immediately after diagnosis. Severity of demen- } \\
\text { tia, age, sex, and education appear to have no significant } \\
\text { effect on this outcome. } \\
\text { Little change was seen in depressive symptoms. In } \\
\text { contrast, symptoms of anxiety seem to decrease after } \\
\text { diagnostic feedback. In particular, individuals who } \\
\text { started the evaluation process with high levels of anxiety } \\
\text { were likely to experience significant relief after they } \\
\text { received diagnostic information. }\end{array}$ & $80 \%$ \\
\hline $\begin{array}{l}\text { Caruana-Pulpan \& } \\
\text { Scerri 2014: } \\
\text { Practices in diag- } \\
\text { nosis, disclosure } \\
\text { and pharmacother- } \\
\text { apeutic manage- } \\
\text { ment of dementia } \\
\text { by GPs: a national } \\
\text { survey. }\end{array}$ & 193 GPs in Malta & Survey, Malta & National survey & $\begin{array}{l}\text { To explore, via a national } \\
\text { survey, the practice } \\
\text { patterns of GPs with } \\
\text { respect to their ability to } \\
\text { diagnose, disclose, and } \\
\text { pharmacotherapeutical- } \\
\text { ly manage dementia in } \\
\text { their primary care } \\
\text { setting }\end{array}$ & $\begin{array}{l}\text { A considerable number of GPs }(62.2 \%) \text { indicated that they } \\
\text { do not routinely disclose the diagnosis, even though } \\
\text { more than half of the respondents were in favor of the } \\
\text { fact that disease disclosure may actually help the patient } \\
\text { and the caregiver in future planning and treatment } \\
\text { decisions. On disclosing, GPs are unsure of the suitable } \\
\text { terminology to use in describing the condition to their } \\
\text { patients and/or caregivers, with dementia being the most } \\
\text { likely used term ( } 33.7 \%) \text { followed by memory problems } \\
(26.4 \%) \text {. Most physicians would prefer to disclose on } \\
\text { being sure of a correct diagnosis and would do so to both } \\
\text { the patient and the caregiver or relative. }\end{array}$ & $80 \%$ \\
\hline
\end{tabular}


Table 1. Continued

\begin{tabular}{|c|c|c|c|c|c|c|}
\hline REFERENCE & PARTICIPANTS & SETTING & DESIGN & AIM & MAIN FINDINGS & JBI \% \\
\hline $\begin{array}{l}\text { Champlin 2020: The } \\
\text { informal care- } \\
\text { giver's lived ex- } \\
\text { perience of being } \\
\text { present with a pa- } \\
\text { tient who receives a } \\
\text { diagnosis of de- } \\
\text { mentia: a phenom- } \\
\text { enological inquiry }\end{array}$ & $\begin{array}{l}12 \text { informal care- } \\
\text { givers }\end{array}$ & USA & $\begin{array}{l}\text { Qualitative } \\
\text { face-to-face } \\
\text { interviews with a } \\
\text { phenomenological } \\
\text { analysis approach }\end{array}$ & $\begin{array}{l}\text { To understand the infor- } \\
\text { mal caregiver's experi- } \\
\text { ence of being present } \\
\text { with a loved one when } \\
\text { he or she receives a } \\
\text { diagnosis of dementia, } \\
\text { and what the constitu- } \\
\text { ents of the meaning that } \\
\text { they assign are. }\end{array}$ & $\begin{array}{l}\text { Caregivers are usually aware that there is something wrong } \\
\text { with the person they care for and can experience feelings } \\
\text { of relief and validation when the diagnosis is disclosed, } \\
\text { which helps lead to a sense of acceptance. Alongside, this } \\
\text { were emotional responses that involved feeling sad, } \\
\text { terrified, worried, and overwhelmed, but coupled with a } \\
\text { need to stay strong. Caregivers watched for an emotional } \\
\text { response in the person with dementia when the diagnosis } \\
\text { was disclosed and reported seeing fear, sadness, and } \\
\text { perhaps confusion, but sometimes no response. Care- } \\
\text { givers reported wanting a road map to help them } \\
\text { navigate the future and understand how they might care } \\
\text { for the person with dementia. }\end{array}$ & $100 \%$ \\
\hline $\begin{array}{l}\text { Connell et al., 2009: } \\
\text { Black and white } \\
\text { adult family mem- } \\
\text { bers' attitudes to- } \\
\text { ward a dementia } \\
\text { diagnosis }\end{array}$ & $\begin{array}{l}178 \text { adults with vary- } \\
\text { ing exposure to } \\
\mathrm{AD} \text { (including } \\
\text { first-degree rela- } \\
\text { tives of people with } \\
\mathrm{AD} \text {, current and } \\
\text { former primary } \\
\text { caregivers of peo- } \\
\text { ple with } \mathrm{AD} \text {, and } \\
\text { those with neither } \\
\text { an affected first- } \\
\text { degree relative nor } \\
\text { an } \mathrm{AD} \text { caregiving } \\
\text { history }\end{array}$ & $\begin{array}{l}\text { Survey in Boston/ } \\
\text { Atlanta, USA }\end{array}$ & $\begin{array}{l}\text { Survey using the } \\
\text { Treatment and Ill- } \\
\text { ness Perceptions } \\
\text { Survey }\end{array}$ & $\begin{array}{l}\text { The primary purpose of } \\
\text { the present study was to } \\
\text { examine potential } \\
\text { benefits of and barriers } \\
\text { to diagnosis from the } \\
\text { perspective of black and } \\
\text { white adults directly af- } \\
\text { fected by AD; a sec- } \\
\text { ondary purpose was to } \\
\text { explore black-white } \\
\text { differences in these } \\
\text { perceptions. }\end{array}$ & $\begin{array}{l}\text { Family members affected by AD endorsed a wide range of } \\
\text { the benefits but few of the barriers to obtaining a } \\
\text { diagnosis examined in this study. The most frequently } \\
\text { endorsed benefits pertained to obtaining information, } \\
\text { finding out what was wrong, and prompting future plans. } \\
\text { In addition to the lack of a cure for AD, the beliefs that } \\
\text { little can be done for someone with AD, that there is a } \\
\text { lack of effective treatment, and that obtaining a diagnosis } \\
\text { was a demanding process for families were the barriers } \\
\text { most frequently endorsed. } \\
\text { Black respondents expressed more positive views of } \\
\text { obtaining a diagnosis than their white counterparts. } \\
\text { Black respondents more likely to strongly endorse a } \\
\text { number of benefits, but they were also less likely to view } \\
\text { the fact that there is currently no cure or effective } \\
\text { treatment as a barrier to diagnosis }\end{array}$ & $100 \%$ \\
\hline $\begin{array}{l}\text { Eccles et al., } 2009 . \\
\text { Improving profes- } \\
\text { sional practice in } \\
\text { the disclosure of a } \\
\text { diagnosis of de- } \\
\text { mentia: a modeling } \\
\text { experiment to } \\
\text { evaluate a theory- } \\
\text { based intervention. }\end{array}$ & $\begin{array}{l}664 \text { individuals from } \\
179 \text { teams. All } \\
\text { professionals who } \\
\text { may deliver a diag- } \\
\text { nosis of dementia }\end{array}$ & $\begin{array}{l}\text { Questionnaire } \\
\text { sent to indivi- } \\
\text { duals within } \\
\text { OAMHTs in } \\
\text { England }\end{array}$ & $\begin{array}{l}\text { A four-arm rando- } \\
\text { mized controlled } \\
\text { trial of the effect of } \\
\text { one theory-based } \\
\text { and two pragmatic } \\
\text { interventions on } \\
\text { the intentions of a } \\
\text { random sample of } \\
\text { members of } \\
\text { OAMHTs }\end{array}$ & $\begin{array}{l}\text { To evaluate a theory- } \\
\text { based intervention } \\
\text { alongside two } \\
\text { pragmatic interven- } \\
\text { tions. A modeling } \\
\text { experiment with the } \\
\text { primary outcome of } \\
\text { intention. }\end{array}$ & $\begin{array}{l}\text { None of the interventions changed intentions or behavioral } \\
\text { simulation scores in relation to finding out what the } \\
\text { patient already knows/suspects about their diagnosis, } \\
\text { using the actual words "dementia" or "Alzheimer's } \\
\text { disease" when talking to the patient or exploring what } \\
\text { the diagnosis means to the patient. }\end{array}$ & $90 \%$ \\
\hline
\end{tabular}


Table 1. Continued

\begin{tabular}{|c|c|c|c|c|c|c|}
\hline REFERENCE & PARTICIPANTS & SETTING & DESIGN & AIM & MAIN FINDINGS & JBI \% \\
\hline $\begin{array}{l}\text { Foley et al., } 2017: \\
\text { "We're certainly } \\
\text { not in our comfort } \\
\text { zone": a qualitative } \\
\text { study of GPs' de- } \\
\text { mentia care educa- } \\
\text { tional needs }\end{array}$ & $\begin{array}{l}14 \text { GPs, } 12 \text { family } \\
\text { carers, and } 5 \text { PwD }\end{array}$ & Ireland & Qualitative interviews & $\begin{array}{l}\text { To explore GP's dementia } \\
\text { care education needs to } \\
\text { inform the development } \\
\text { of a primary care } \\
\text { dementia educational } \\
\text { program. }\end{array}$ & $\begin{array}{l}\text { All participants expressed the importance of disclosure and } \\
\text { the need for GPs to receive training on how to disclose } \\
\text { sensitively. } \\
\text { The need for GPs to provide information on sources of } \\
\text { support and local community-based health and social } \\
\text { care services was widely expressed. } \\
\text { Some GPs recognized that their role included supporting } \\
\text { people through the emotional impact of what can be a } \\
\text { devastating diagnosis. However, GPs tended not to } \\
\text { identify counseling as a training need, even though } \\
\text { carers and PwD did. }\end{array}$ & $85 \%$ \\
\hline $\begin{array}{l}\text { Giezendanner et al., } \\
\text { 2018: Early diag- } \\
\text { nosis and manage- } \\
\text { ment of dementia } \\
\text { in general practice } \\
\text { - how do Swiss } \\
\text { GPs meet the } \\
\text { challenge? }\end{array}$ & 882 GPs & Switzerland & Survey & $\begin{array}{l}\text { To explore GPs' approach } \\
\text { to the diagnosis, dis- } \\
\text { closure, and manage- } \\
\text { ment of dementia, and } \\
\text { their perception of the } \\
\text { provision of care and } \\
\text { health services for indi- } \\
\text { viduals with dementia } \\
\text { via a national survey. }\end{array}$ & $\begin{array}{l}\text { Three quarters of respondents disclosed the diagnosis } \\
\text { themselves, with only } 9 \% \text { reporting that they almost } \\
\text { never or never took on this role. Almost } 90 \% \text { reported } \\
\text { that disclosures involved the person with dementia and } \\
\text { their family members. Disclosures lasted an average of } \\
28.5 \text { minutes. }\end{array}$ & $100 \%$ \\
\hline $\begin{array}{l}\text { Grill et al., 2017: } \\
\text { Communicating } \\
\text { MCI diagnoses } \\
\text { with and without } \\
\text { amyloid imaging }\end{array}$ & 19 experts & USA & Workgroup meeting & $\begin{array}{l}\text { To identify recommenda- } \\
\text { tions and best practices } \\
\text { for delivering a diagno- } \\
\text { sis of MCI. }\end{array}$ & $\begin{array}{l}\text { Patients should be provided with a written summary of the } \\
\text { diagnosis and treatment recommendations, services } \\
\text { available, and local resources. } \\
\text { Careful, honest, and compassionate dialog should be used } \\
\text { to help patients validate and understand their condition. } \\
\text { Patients should have the opportunity to discuss whether } \\
\text { they would like further testing, for example, amyloid } \\
\text { imaging, and what the implications are for clinical } \\
\text { management. The clinician should discuss what the } \\
\text { patient and their family can expect from the scan, and } \\
\text { the limitations of it. The results of amyloid scans should } \\
\text { be delivered in person and described using terminology } \\
\text { related to the presence or absence of amyloid and not the } \\
\text { amount or any link to severity. Clinicians should explain } \\
\text { that negative scans do not mean absence of illness, and } \\
\text { that positive scans represent a risk for further decline. } \\
\text { Clinicians may wish to review the images of the scans } \\
\text { with patients. }\end{array}$ & $85 \%$ \\
\hline
\end{tabular}


Table 1. Continued

\begin{tabular}{|c|c|c|c|c|c|c|}
\hline REFERENCE & PARTICIPANTS & SETTING & DESIGN & AIM & MAIN FINDINGS & JBI \% \\
\hline $\begin{array}{l}\text { Grossberg et al., } \\
\text { 2010: } \\
\text { The art of sharing the } \\
\text { diagnosis and } \\
\text { management of } \\
\text { AD with patients } \\
\text { and caregivers: re- } \\
\text { commendations of } \\
\text { an expert consen- } \\
\text { sus panel }\end{array}$ & $\begin{array}{l}6 \text { academic or practi- } \\
\text { cing physicians }\end{array}$ & USA & $\begin{array}{l}\text { Roundtable discus- } \\
\text { sion with an expert } \\
\text { consensus panel }\end{array}$ & $\begin{array}{l}\text { To generate recommen- } \\
\text { dations for PCPs in } \\
\text { communicating the di- } \\
\text { agnosis and manage- } \\
\text { ment of AD. }\end{array}$ & $\begin{array}{l}\text { The diagnosis should be a process rather than an event, } \\
\text { over several visits, to introduce the possibility of a } \\
\text { diagnosis gradually. } \\
\text { Family members should be present at disclosure and } \\
\text { subsequent visits to help the physician to communicate } \\
\text { the diagnosis effectively. } \\
\text { Diagnoses should be disclosed in a private, comfortable, } \\
\text { quiet location, with ample time for the visit. Distractions } \\
\text { such as phone calls should be avoided. } \\
\text { Specific language, for example, Alzheimer's should be used } \\
\text { unless cultural, educational, or other factors deem this } \\
\text { inappropriate. Because of the negative connotations, } \\
\text { physicians should try to emphasize hopeful aspects, such } \\
\text { as functioning that is preserved and capabilities that the } \\
\text { PwD has. } \\
\text { Physicians should position themselves as a partner of and } \\
\text { advocate for the PwD and their family, and a tailored } \\
\text { approach should be taken. } \\
\text { Physicians should discuss with carers what stage the PwD } \\
\text { is at and the likely prognosis for the next } 6 \text { months, and } \\
\text { what resources may be helpful. Basic literature should be } \\
\text { provided. Discussions about driving should begin early } \\
\text { in process. }\end{array}$ & $100 \%$ \\
\hline $\begin{array}{l}\text { Hansen et al., 2008: } \\
\text { GPs' experiences } \\
\text { and understand- } \\
\text { ings of diagnosing } \\
\text { dementia: factors } \\
\text { impacting on early } \\
\text { diagnosis }\end{array}$ & 25 GPs & Australia & $\begin{array}{l}\text { Focus groups and } \\
\text { semi-structured in- } \\
\text { terviews }\end{array}$ & $\begin{array}{l}\text { To achieve a greater } \\
\text { understanding of de- } \\
\text { mentia diagnosis from } \\
\text { the perspective of GPs. }\end{array}$ & $\begin{array}{l}\text { GPs reported that rather than disclose the diagnosis using } \\
\text { explicit terms, a discussion over a number of consulta- } \\
\text { tions is preferred, where the PwD can begin to realize for } \\
\text { themselves that they have memory problems. GPs made } \\
\text { judgemnts about whether the PwD would be comfor- } \\
\text { table with explicit terms and when it would be } \\
\text { appropriate to talk to them about the issue. }\end{array}$ & $80 \%$ \\
\hline $\begin{array}{l}\text { Hillman 2017: Diag- } \\
\text { nosing dementia: } \\
\text { ethnography, in- } \\
\text { teractional ethics } \\
\text { and everyday mor- } \\
\text { al reasoning }\end{array}$ & $\begin{array}{l}51 \text { consultations ob- } \\
\text { served } 13 \text { inter- } \\
\text { views with memory } \\
\text { clinic staff }\end{array}$ & $\mathrm{UK}$ & $\begin{array}{l}\text { Observations in } \\
\text { memory clinics }\end{array}$ & $\begin{array}{l}\text { To explore the construc- } \\
\text { tion of morals while } \\
\text { highlighting the } \\
\text { social, collaborative, } \\
\text { and processual nature } \\
\text { of reaching a diagnosis. }\end{array}$ & $\begin{array}{l}\text { Each person should be treated individually and there are } \\
\text { no text book rules about how to disclose. } \\
\text { Clinicians expressed a tension between recognizing that the } \\
\text { patient is an individual with the capacity to make free } \\
\text { and reasoned choices, and that the diagnosis cannot be } \\
\text { disentangled from the perceptions, needs, and concerns } \\
\text { of other people in the patient's life who might need more } \\
\text { information. }\end{array}$ & $90 \%$ \\
\hline
\end{tabular}


Table 1. Continued

\begin{tabular}{|c|c|c|c|c|c|c|}
\hline REFERENCE & PARTICIPANTS & SETTING & DESIGN & AIM & MAIN FINDINGS & JBI \% \\
\hline & & & & & $\begin{array}{l}\text { Disciplinary and organizational cultures play a role in } \\
\text { framing the consultation, where the impetus is on } \\
\text { achieving the correct diagnosis in a reliable way, rather } \\
\text { than on how it is delivered. } \\
\text { Clinicians face a tension between wanting to use time as a } \\
\text { resource to build up to delivering the diagnosis, but also } \\
\text { feeling under pressure to not provide another appoint- } \\
\text { ment and instead to apply a diagnostic label, diagnose } \\
\text { promptly and free up appointments for other people in } \\
\text { the face of increasing caseloads. } \\
\text { Visual evidence from CT scans can help clinicians frame } \\
\text { the diagnosis in an objective way and show the transition } \\
\text { from memory problems to a diagnosis and move the } \\
\text { conversation toward treatment and intervention plans. }\end{array}$ & \\
\hline $\begin{array}{l}\text { Innes et al., 2014: } \\
\text { Dementia diagno- } \\
\text { sis and post- } \\
\text { diagnostic support } \\
\text { in Scottish rural } \\
\text { communities: ex- } \\
\text { periences of PwD } \\
\text { and their families }\end{array}$ & $\begin{array}{l}18 \text { participants } \\
\text { (6 PwD and } 12 \\
\text { carers) }\end{array}$ & Scotland & Qualitative interviews & $\begin{array}{l}\text { To report service user } \\
\text { views about diagnostic } \\
\text { processes in a remote } \\
\text { and rural region. }\end{array}$ & $\begin{array}{l}\text { Most diagnoses were delivered face to face by a clinician. } \\
\text { Participants wanted to receive an explanation and more } \\
\text { information and support regarding available care. } \\
\text { Participants reported that nothing was explained when } \\
\text { they were diagnosed. } \\
\text { Participants reported feeling the diagnosis came as a shock, } \\
\text { despite an awareness of their memory problems prior to } \\
\text { assessment. }\end{array}$ & $70 \%$ \\
\hline $\begin{array}{l}\text { Kaduszkiewicz et al., } \\
\text { 2008: Telling "the } \\
\text { truth" in dementia } \\
\text { - Do attitude and } \\
\text { approach of GPs } \\
\text { and specialists } \\
\text { differ? }\end{array}$ & $\begin{array}{l}30 \text { GPs participated } \\
\text { in qualitative } \\
\text { interviews } \\
307 \text { respondents to } \\
\text { the questionnaire } \\
\text { (211 GPs and } 96 \\
\text { specialists) }\end{array}$ & Germany & $\begin{array}{l}\text { Qualitative interviews } \\
\text { and a question- } \\
\text { naire developed } \\
\text { from the interview } \\
\text { data }\end{array}$ & $\begin{array}{l}\text { To systematically investi- } \\
\text { gate differences } \\
\text { between GPs and } \\
\text { specialists with regard } \\
\text { to diagnosis and } \\
\text { disclosure of dementia. }\end{array}$ & $\begin{array}{l}\text { GPs reported that patients deny their diagnosis when it is } \\
\text { disclosed and try to convey that all is well. } \\
\text { GPs worried about ruining the doctor-patient relationship } \\
\text { and avoid conflict with the patient. } \\
21 \text { GPs reported using language other than dementia or } \\
\text { Alzheimer's and instead use terms like normal aging } \\
\text { process or attribute it to circulatory issues. } \\
\text { Both specialists and GPs tended to report more details of } \\
\text { the diagnosis to the relatives rather than the patient and use } \\
\text { explicit terms. Only one-third of specialists and half of GPs } \\
\text { used the terms Alzheimer's and dementia with patients. } \\
\text { A large proportion of GPs strongly ( } 35 \% \text { ) or partially ( } 40 \%) \\
\text { confirmed that patients felt ashamed when confronted with } \\
\text { signs of cognitive impairment. Results from specialists were } \\
\text { similar. } \\
50 \% \text { of GPs and } 30 \% \text { of specialists were interested in further } \\
\text { training concerning communication with PwD and } \\
\text { relatives. }\end{array}$ & $75 \%$ \\
\hline
\end{tabular}


Table 1. Continued

\begin{tabular}{|c|c|c|c|c|c|c|}
\hline REFERENCE & PARTICIPANTS & SETTING & DESIGN & AIM & MAIN FINDINGS & JBI $\%$ \\
\hline $\begin{array}{l}\text { Karneili-Miller et al., } \\
\text { 2012: Expecta- } \\
\text { tions, experiences, } \\
\text { and tensions in the } \\
\text { memory clinic: the } \\
\text { process of diagno- } \\
\text { sis disclosure of } \\
\text { dementia within a } \\
\text { triad }\end{array}$ & $\begin{array}{l}10 \text { patients and } 17 \\
\text { companions }\end{array}$ & $\begin{array}{l}\text { Two memory } \\
\text { clinics in Israel }\end{array}$ & $\begin{array}{l}\text { Qualitative interviews } \\
\text { using grounded } \\
\text { theory after the } \\
\text { visit to the memory } \\
\text { clinic }\end{array}$ & $\begin{array}{l}\text { To identify patients' and } \\
\text { companions' expecta- } \\
\text { tions, perceptions, and } \\
\text { experiences regarding } \\
\text { first time encounters } \\
\text { that deal with assess- } \\
\text { ment and disclosure of } \\
\text { the dementia diagnosis. }\end{array}$ & $\begin{array}{l}\text { Many patients expressed disappointment or discontent } \\
\text { following the consultations due to an absence of tangible } \\
\text { solutions or due to the physician's style of interaction } \\
\text { and communication with the patient and companion. } \\
\text { For example, patients felt disempowered when physi- } \\
\text { cians spoke directly to the companion instead of them. } \\
\text { There is a difference in perspective between patients who } \\
\text { endorsed their memory difficulties and those who did } \\
\text { not, with the latter experiencing more offense. } \\
\text { Companions wanted an explicit explanation of what they } \\
\text { can and should do, where they might receive support } \\
\text { and guidance. However, companions expressed that they } \\
\text { were not given solutions and guidance. } \\
\text { Some companions felt a follow-up session to deepen their } \\
\text { understanding was necessary. The lack of details } \\
\text { provided in the session left companions feeling insecure } \\
\text { about how to proceed. } \\
\text { Some companions reported that the physician expressed } \\
\text { impatience and even contempt toward the PwD, making } \\
\text { rude interruptions. } \\
\text { Some companions, however, expressed that they were glad } \\
\text { someone was listening and was sympathetic to their } \\
\text { feelings. Companions whose struggles and efforts were } \\
\text { recognized and acknowledged felt reassured and } \\
\text { empowered. }\end{array}$ & $70 \%$ \\
\hline $\begin{array}{l}\text { Laakkonen et al., } \\
\text { 2008: How do } \\
\text { elderly spouse } \\
\text { caregivers of } \\
\text { people with AD } \\
\text { experience the } \\
\text { disclosure of } \\
\text { dementia diagnosis } \\
\text { and subsequent } \\
\text { care? }\end{array}$ & $\begin{array}{l}1214 \text { spousal carers } \\
\text { of people with } \mathrm{AD} \\
\text { (1943 sampled to } \\
\text { participate) } \\
63 \text { spousal carers } \\
\text { participated in the } \\
\text { qualitative part }\end{array}$ & Finland & $\begin{array}{l}\text { Postal questionnaire } \\
\text { and qualitative } \\
\text { interviews }\end{array}$ & $\begin{array}{l}\text { To explore participants } \\
\text { experiences regarding } \\
\text { diagnosis disclosure } \\
\text { and subsequent need } \\
\text { for advance care } \\
\text { planning. }\end{array}$ & $\begin{array}{l}97 \% \text { of carers preferred that the physician openly informed } \\
\text { the PwD of the dementia diagnosis. } 55 \% \text { of the carers } \\
\text { felt their spouse had developed depressive symptoms } \\
\text { after disclosure, and } 68 \% \text { of carers felt that their } \\
\text { awareness of the dementia had caused them grief or } \\
\text { symptoms of depression. } \\
\text { Carers in the qualitative study described feelings of } \\
\text { hopelessness and loneliness, with particular examples } \\
\text { occurring when they had not been invited for a follow-up } \\
\text { appointment with the physician. Carers expressed } \\
\text { feelings of uncertainty and anxiety, due to not knowing } \\
\text { where to get help or what to do next. Carers felt } \\
\text { disappointed with the lack of support and follow-up care } \\
\text { and felt uncertain about the prognosis. }\end{array}$ & $80 \%$ \\
\hline
\end{tabular}


Table 1. Continued

Some carers felt guilty about not asking enough questions, and some reported not knowing the right questions to ask. Carers expressed a desire for a further appointment once they had absorbed the information and understood it better.

Lecouturier et al., 2008:

\section{PwD}

6 informal carers

Appropriate disclosure of a diagnosis of dementia: identifying the key behaviors of "best practice"

Lee \& Weston 2011:

Disclosing a diagnosis of dementia: helping learners to break bad news
8 panelists (health and social care professionals)
UK
Mixed methods approach involving a literature review, semi-structured interviews, and a consensus panel process involving a questionnaire and a meeting

Opinion piece
To identify key components of the process of disclosure and to identify the range of disclosure behaviors using three different methods.

The literature review revealed a total of 199 components of $70 \%$ appropriate disclosure.

The interviews identified 112 behaviors.

The questionnaire completed by the panelists identified 55 behaviors.

Of the total 220 behaviors identified, 109 overlapped.

Behaviors could be grouped into 8 categories: 1. preparing for disclosure, 2 . integrating family members, 3 . exploring the patient's perspective, 4 . disclosing the diagnosis, 5. responding to patient's reactions, 6 . focusing on QoL and well-being, 7. planning for the future, and 8. communicating effectively.

Suggestions for disclosure include determining what the patient already knows about dementia and addressing

To provide advice and strategies for disclosure of a dementia diagnosis, especially for those

teaching others how to do it misconceptions that may have arisen from experiences. Dementia might be described as part of a continuum of memory loss, with emphasis placed on preservation of function in the early stages.

To provide realistic hope by highlighting individual variation in the manifestation and progression of dementia, and availability of treatment options. Healthcare professionals may discuss how to manage dementia and therapeutic options available.

Healthcare professionals should emphasize nonabandonment and facilitate a caring committed relationship between PwD and the family physician.

Lim et al., 2016: Disclosure of positron emission tomography amyloid imaging results: preliminary study of safety and tolerability
11 participants who were part of a larger study $(n=63)$ who wished to know their biomarker results
Academic memory disorder clinics, Rhode Island, USA
Part of a larger trial to To evaluate the conseinvestigate preclinical AD biomarkers. Participants who wished to know their status were told and then completed a follow-up psychoeducational pro-

gram and

structured

interviews. (AB) disclosure on risks of $\mathrm{AD}$. quences of amyloid beta mood, subjective sense of memory impairment, lifestyle, and perceived

Participants who had a negative AB result were relieved but conscious and it could change over time. Participants with a positive $A B$ result were anxious but not surprised and had shared this information with others and sought additional information on the internet.

AB positive participants had made lifestyle changes and experienced no negative effects on their mood or subjective sense of memory impairment.

A psychoeducational brochure provided helped participants to understand the link between environmental and genetic risk factors and the future progression to $\mathrm{AD}$, and they found it useful and informative. The brochure did change perceptions of risk for participants (either $A B$ positive or negative). 
Table 1. Continued

\begin{tabular}{|c|c|c|c|c|c|c|}
\hline REFERENCE & PARTICIPANTS & SETTING & DESIGN & AIM & MAIN FINDINGS & JBI \% \\
\hline $\begin{array}{l}\text { Lingler et al., 2016: } \\
\text { Development of a } \\
\text { standardized ap- } \\
\text { proach to disclos- } \\
\text { ing amyloid } \\
\text { imaging research } \\
\text { results in MCI }\end{array}$ & $\begin{array}{l}10 \text { dyads (carer and } \\
\text { person with MCI) } \\
\text { involved in a si- } \\
\text { mulated disclosure } \\
\text { and one-to-one in- } \\
\text { terviews, and } 8 \text { of } \\
\text { these ( } 4 \text { with MCI } \\
\text { and } 4 \text { carers) par- } \\
\text { ticipated in a focus } \\
\text { group }\end{array}$ & $\begin{array}{l}\text { Alzheimer's Dis- } \\
\text { ease Research } \\
\text { Center, Univer- } \\
\text { sity of Pitts- } \\
\text { burgh, USA }\end{array}$ & $\begin{array}{l}\text { Simulated disclo- } \\
\text { sures of PET re- } \\
\text { sults (4 positive, } 4 \\
\text { negative, and } 4 \text { in- } \\
\text { conclusive) with } \\
\text { one-to-one inter- } \\
\text { views to complete a } \\
\text { survey and then a } \\
\text { focus group with } 8 \\
\text { of the participants }\end{array}$ & $\begin{array}{l}\text { To test materials devel- } \\
\text { oped for use prior to } \\
\text { amyloid imaging and } \\
\text { when disclosing results } \\
\text { of amyloid imaging in } \\
\text { the context of MCI. }\end{array}$ & $\begin{array}{l}\text { Surveys revealed that participants were satisfied with the } \\
\text { disclosure process. All participants had also taken a } \\
\text { health literacy test, and half of those with MCI showed a } \\
\text { lack of health literacy, confirming the need to have } \\
\text { disclosure sessions with a companion present. } \\
\text { A theme from the focus group of best practice recom- } \\
\text { mendations suggested the following ideas: offer pretest } \\
\text { counseling, use clear graphics, review patients' brain } \\
\text { image scans in the disclosure, offer take-home materials } \\
\text { describing follow-up options, call patients post- } \\
\text { disclosure to answer emerging questions, and commu- } \\
\text { nicate seamlessly with primary care providers. } \\
\text { A second theme was that knowledge is power, and despite } \\
\text { the outcome of the tests participants generally felt that } \\
\text { knowing enabled them to be strong and to make } \\
\text { decisions about their futures. }\end{array}$ & $60 \%$ \\
\hline $\begin{array}{l}\text { Manthorpe et al., } \\
\text { 2013: } \\
\text { From forgetfulness to } \\
\text { dementia: clinical } \\
\text { and commission- } \\
\text { ing implications of } \\
\text { diagnostic } \\
\text { experiences }\end{array}$ & $\begin{array}{l}27 \text { people with mem- } \\
\text { ory problems and } \\
26 \text { supporters or } \\
\text { carers }(20 \text { of which } \\
\text { were matched } \\
\text { pairs) }\end{array}$ & $\begin{array}{l}\text { UK memory } \\
\text { clinics }\end{array}$ & Qualitative interviews & $\begin{array}{l}\text { To increase understand- } \\
\text { ing of the experiences of } \\
\text { people developing de- } \\
\text { mentia and of their } \\
\text { carers and to inform } \\
\text { practice and decision- } \\
\text { making. }\end{array}$ & $\begin{array}{l}\text { Patients and carers felt that communication was not } \\
\text { necessarily a dialog as although there was time for } \\
\text { questions in the consult, many did not know what to ask } \\
\text { or what information they might need. } \\
\text { Some felt they received enough information, but others felt } \\
\text { their concerns and questions were disregarded by } \\
\text { physicians telling them they were okay. } \\
\text { Support tended to be generic rather than person-centered } \\
\text { and in response to their concerns. }\end{array}$ & $70 \%$ \\
\hline $\begin{array}{l}\text { Mastwyk et al., 2014: } \\
\text { Disclosing a de- } \\
\text { mentia diagnosis: } \\
\text { what do patients } \\
\text { and family consid- } \\
\text { er important? }\end{array}$ & $\begin{array}{l}32 \text { patient-carer } \\
\text { dyads }\end{array}$ & $\begin{array}{l}\text { Australian mem- } \\
\text { ory clinics }\end{array}$ & $\begin{array}{l}\text { Semi-structured in- } \\
\text { terviews and use of } \\
\text { feedback sheets to } \\
\text { record what was } \\
\text { discussed during } \\
\text { the appointment }\end{array}$ & $\begin{array}{l}\text { To identify helpful strate- } \\
\text { gies for clinicians in } \\
\text { meeting the wants and } \\
\text { needs of this patient } \\
\text { group and those of their } \\
\text { families. }\end{array}$ & $\begin{array}{l}\text { Several patients reported that the disclosure should be } \\
\text { direct, even though it would be a shock, although some } \\
\text { patients felt it depended on the individual and should be } \\
\text { done sensitively. Carers' views were very similar. } \\
\text { Patients felt that the doctor should be sure of the diagnosis } \\
\text { before it was disclosed. } \\
\text { Attributes of doctors considered a requirement for this role } \\
\text { were supportive, being a good listener, and being easy to } \\
\text { understand. } \\
\text { Carers felt that they did not receive enough information } \\
\text { during the disclosure. } \\
55 \% \text { of patients preferred to receive all information about } \\
\text { the diagnosis, treatment, and prognosis all at once and } \\
\text { up-front, whereas } 35 \% \text { preferred to receive it in stages. } \\
75 \% \text { of patients felt that written information should }\end{array}$ & $65 \%$ \\
\hline
\end{tabular}


Table 1. Continued

accompany this. Carers were equally divided with $50 \%$ favoring an up-front approach, and $50 \%$ preferring to receive it in stages. Those favoring an up-front approach felt it was necessary for planning and to manage issues such as driving. $80 \%$ of carers felt written information would be helpful.

Carers appreciated physicians who provided a sense of hope through explaining how/where to get further treatment and felt that this empowered them.

McCabe et al., (2019): Patient and companion shared decisionmaking and satisfaction with deci-

sions about starting cholinesterase medication at de-

mentia diagnosis

Milby et al., 2017: Diagnosis disclosure in dementia: understanding the experiences of clinicians and patients who have recently given or received a

diagnosis

\section{4 patients \\ 69 companions \\ 21 doctors}

\section{7 patients}

8 clinicians

England
Video observations of To examine how decidisclosure meetings and standardized self-report measures

Qualitative interviews To explore the lived exwith interpretative phenomenological analysis sions are made about whether to start cholinesterase inhibitors at diagnosis disclosure meetings. perience of individuals who have recently given or recently received a diagnosis of dementia.

Patients and companions completed the Patient Experience Questionnaire about their disclosure meeting and $59.7 \%$ of patients and $35.9 \%$ of companions expressed uncertainty on the outcome scale, $51.5 \%$ of patients and $26.8 \%$ of companions reported barriers to communication, and $53 \%$ of patients and $21.7 \%$ of companions felt negative or no positive emotion. $4.6 \%$ of patients described communication as less than optimal. Overall, patient experience of the disclosure meeting was somewhat negative.

Reactions to receiving a diagnosis described by both patients and clinicians involved shock, fear, and acceptance, but the most common reactions are denial and avoidance. Patients use avoidance to manage their loss of sense of self and anxieties about the future, and

clinicians use avoidance by not using explicit terms due to a lack of certainty about the diagnosis, and a desire to minimize distress, as well as respect for patients' wishes not to know the diagnosis.

Supportive staff at the MAS put patients at ease and help them to engage with the process. However, a diagnosis delivered without provision of information contributed toward anxiety.

Clinicians reported that working with other members of health and social care helped to facilitate post-diagnostic support. Working with other staff also helps to increase confidence in the diagnosis.

Clinicians reported that disclosure was draining and that patients' distress does affect them. Being able to share this 
Table 1. Continued

with a colleague helps to minimize the personal impact.

Clinicians felt that a further appointment was needed after disclosure, with the same professional who had disclosed, but heavy caseloads meant that this was often not available.

\section{Moore \& Cahill 2013: 9 GPs}

Diagnosis and dis-

closure of dementia:

a comparative study

of Irish and Swedish

GPs

Mormont et al.,

2012:

Experiences of the patients and their caregivers regarding the disclosure of the diagnosis of $\mathrm{AD}$ : a Belgian retrospective survey

107 patients and 107 Belgium matched caregivers attending a memory clinic over 1

year

Ireland and

Sweden

\section{with thematic \\ analysis}

Structured interview To report the experience and agreement/disagreement of patients and caregivers regarding $\mathrm{AD}$ diagnosis disclosure.
Nielsen et al., 2018: The process of disclosing a diagnosis of dementia and MCI: a national survey of specialist physicians in Denmark
54 specialist physicians (80 invited to participate, response rate $68 \%$ )
Denmark
Online questionnaire To investigate the process and content of diagnostic disclosure meetings in Danish dementia diagnostic services
Only three participants claimed they would normally talk openly about dementia when disclosing the diagnosis, instead six of the GPs tended to explicitly avoid using the word dementia.

$29 \%$ of patients declared that they had suffered from the disclosure, but caregivers reported only $15 \%$ of patients were still suffering. $85 \%$ of caregivers felt the diagnosis had been useful.

Patients who could remember their diagnosis significantly more frequently reported that they had suffered compared to those who could not recall, and that they were more anxious.

Caregivers of patients who could remember their diagnosis reported significantly more frequently that the patient had suffered and was still suffering from the disclosure, with a reaction of sadness, depression, anxiety, but also satisfaction to receive an explanation.

The disclosure of $\mathrm{AD}$ was responsible for anxiety or sadness in approximately one-third of patients.

$98 \%$ reported that disclosure is almost always/often performed by a physician and $61 \%$ reported that a nurse almost always/often participated in these meetings.

$54 \%$ never/rarely disclosed on the first encounter. $56 \%$ had the opportunity to find out expectations before the meeting, but for $31 \%$ this was never/rarely possible.

$98 \%$ of participants almost always/often discussed pharmacological treatments at the disclosure meeting and $64 \%$ offered follow-up (although $28 \%$ never/rarely did so). $95 \%$ provided information on psychosocial support. $81 \%$ provided written materials to support the verbal information.

Patients were encouraged to bring a family caregiver to the disclosure meeting and most participants disclosed to them jointly.

$78 \%$ of participants regularly used the term $\mathrm{AD}$ or dementia of the AD type (52\%), or dementia (39\%). No respondents used terms senility or age-related impairment. 
Table 1. Continued

\begin{tabular}{|c|c|c|c|c|c|c|}
\hline REFERENCE & PARTICIPANTS & SETTING & DESIGN & AIM & MAIN FINDINGS & JBI \% \\
\hline & & & & & $\begin{array}{l}\text { Most respondents shared results from brain scans/assessments } \\
\text { and informed on etiology, progression, causes of symptoms. } \\
\text { However, few respondents gave information on prognosis } \\
\text { and future symptoms, and the amount of information given } \\
\text { was dependent on the degree of cognitive impairment, the } \\
\text { specific type of dementia, and the level of emotional distress. } \\
100 \% \text { of respondents discussed issues such as handling } \\
\text { medications and } 87 \% \text { discussed driving. }\end{array}$ & \\
\hline $\begin{array}{l}\text { Page et al., 2015: } \\
\text { "Rydym Eisiau } \\
\text { Gwybod" the de- } \\
\text { mentia diagnosis } \\
\text { disclosure prefer- } \\
\text { ences of people in } \\
\text { North Wales }\end{array}$ & $\begin{array}{l}253 \text { PwD attending } \\
\text { memory assess- } \\
\text { ment services }\end{array}$ & North Wales, UK & Clinical audit & $\begin{array}{l}\text { To quantify patients' pre- } \\
\text { ferences for diagnostic } \\
\text { disclosure }\end{array}$ & $\begin{array}{l}84.1 \% \text { of patients included in the audit preferred their } \\
\text { diagnosis to be disclosed jointly to themselves and a } \\
\text { relative or } 2.7 \% \text { to themselves and a third party (a carer). } \\
8.3 \% \text { of patients preferred to receive their diagnosis } \\
\text { alone. All but one of the } 4.7 \% \text { of those who did not want } \\
\text { to know wanted their diagnosis to be disclosed to a } \\
\text { relative. }\end{array}$ & $60 \%$ \\
\hline & & & & & $\begin{array}{l}\text { Patients who expressed a preference for non-disclosure } \\
\text { were } 5.74 \text { times more likely to not have their preferences } \\
\text { actioned than those requesting disclosure. } \\
\text { Patients requesting joint disclosure were less likely to have } \\
\text { their preferences ignored, suggesting the companion } \\
\text { represents a reassuring presence not just for the PwD but } \\
\text { also for the healthcare professional. }\end{array}$ & \\
\hline $\begin{array}{l}\text { Peel 2015: Diagnos- } \\
\text { tic communication } \\
\text { in the memory } \\
\text { clinic: a conversa- } \\
\text { tion analytic } \\
\text { perspective }\end{array}$ & $\begin{array}{l}15 \text { patients attending } \\
\text { memory clinics } \\
\text { and } 14 \text { accompa- } \\
\text { nying persons }\end{array}$ & $\begin{array}{l}\text { One memory } \\
\text { clinic in } \\
\text { England }\end{array}$ & $\begin{array}{l}\text { Video recording and } \\
\text { conversation ana- } \\
\text { lysis of memory } \\
\text { clinic appoint- } \\
\text { ments }\end{array}$ & $\begin{array}{l}\text { To understand why pre- } \\
\text { vious literature labels } \\
\text { the disclosure process } \\
\text { as difficult and to gen- } \\
\text { erate patient-oriented } \\
\text { advice on the process }\end{array}$ & $\begin{array}{l}\text { Patients tend not to agree or acknowledge the news } \\
\text { delivered by the doctor, even when doctors take an } \\
\text { affiliative conversation style by including the patient in } \\
\text { the conversation. } \\
\text { Bad news tends to be "shrouded" with positives. } \\
\text { Some interactions do not necessarily need the diagnostic } \\
\text { labels to be explicit for the diagnosis to be commu- } \\
\text { nicated. Unambiguous naming of dementia/AD does not } \\
\text { always help the patient understand what is happening. } \\
\text { Diagnosis is an ongoing, repetitive discussion between } \\
\text { healthcare professionals, patients, and carers. } \\
\text { Patients themselves tend to normalize their experience, and } \\
\text { doctors interact with this, which presents the doctor with } \\
\text { a situational dilemma of having a smooth consultation } \\
\text { but also not deceiving patients and giving them the } \\
\text { opportunity of a timely diagnosis. }\end{array}$ & $80 \%$ \\
\hline
\end{tabular}


Table 1. Continued

\begin{tabular}{|c|c|c|c|c|c|c|}
\hline REFERENCE & PARTICIPANTS & SETTING & DESIGN & AIM & MAIN FINDINGS & JBI $\%$ \\
\hline $\begin{array}{l}\text { Philips et al., 2012: } \\
\text { Difficulties in } \\
\text { disclosing the } \\
\text { diagnosis of de- } \\
\text { mentia: a qualita- } \\
\text { tive study in } \\
\text { general practice }\end{array}$ & $21 \mathrm{GPs}$ & Australia & Qualitative interviews & $\begin{array}{l}\text { To explore GPs' percep- } \\
\text { tions of barriers to dis- } \\
\text { closing the diagnosis of } \\
\text { dementia }\end{array}$ & $\begin{array}{l}\text { Disclosure was felt to be difficult if GPs perceived patients } \\
\text { to be hiding or denying symptoms of dementia. } \\
\text { Disclosure is easier if the patient is already thinking } \\
\text { about that diagnosis. } \\
\text { GPs in this study reported feeling a sense of trepidation } \\
\text { about disclosure as patients were often fearful of the } \\
\text { diagnosis. GPs felt that if there was a well-developed } \\
\text { doctor-patient relationship, they should be the one to } \\
\text { disclose though, rather than a specialist who may not be } \\
\text { known to the patient. However, some participants felt } \\
\text { that the specialist could occupy a position of blame, and } \\
\text { the GP was then in a position to support their patients. } \\
\text { Some GPs felt that disclosure would impact the doctor- } \\
\text { patient relationship. } \\
\text { Family members were felt to be helpful as they usually } \\
\text { wanted to know more information, which the GP could } \\
\text { focus on, especially if the patient discounted the } \\
\text { implications of the diagnosis. Providing education to } \\
\text { carers about the patient's behavior was felt to be } \\
\text { important to help them cope with the consequences of } \\
\text { the condition. } \\
\text { GPs felt it was important to offer hope during the } \\
\text { disclosure by confirming peoples' fears and giving them } \\
\text { a constructive way to move forward. } \\
\text { Some GPs reported using terms such as memory impair- } \\
\text { ment rather than dementia to avoid negative connota- } \\
\text { tions of the word dementia. }\end{array}$ & $70 \%$ \\
\hline $\begin{array}{l}\text { Porteri et al., 2010: } \\
\text { Diagnosis disclosure } \\
\text { of prodromal AD: } \\
\text { ethical analysis of } \\
\text { two cases }\end{array}$ & Two patient cases & Europe & $\begin{array}{l}\text { Description of two } \\
\text { clinical cases }\end{array}$ & $\begin{array}{l}\text { To consider if and how } \\
\text { diagnosis should be } \\
\text { disclosed in two cases } \\
\text { from an ethical } \\
\text { perspective. }\end{array}$ & $\begin{array}{l}\text { Patients should be given the choice whether to receive the } \\
\text { results or not before the assessments take place, and } \\
\text { patients should have the chance to change their mind at } \\
\text { any point. } \\
\text { The authors suggest that due to the lack of effective } \\
\text { treatments, a truthful diagnosis disclosure is not } \\
\text { necessary to guarantee the best available treatment in } \\
\text { prodromal AD. } \\
\text { Disclosure and the terminology used should be based on } \\
\text { the patient's current socio-personal context, considering } \\
\text { their mood and family support. } \\
\text { Biomarkers should be treated with caution as the presence } \\
\text { of biomarkers does not necessarily translate into the } \\
\text { same clinical situation in the future. }\end{array}$ & $100 \%$ \\
\hline
\end{tabular}


Table 1. Continued

\begin{tabular}{|c|c|c|c|c|c|c|}
\hline REFERENCE & PARTICIPANTS & SETTING & DESIGN & AIM & MAIN FINDINGS & JBI \% \\
\hline $\begin{array}{l}\text { Raicher et al., 2008: } \\
\text { AD diagnosis dis- } \\
\text { closure in Brazil: a } \\
\text { survey of specia- } \\
\text { lized physicians' } \\
\text { current practice } \\
\text { and attitudes }\end{array}$ & $\begin{array}{l}181 \text { physicians (of a } \\
\text { possible sample of } \\
970 \text { potential } \\
\text { respondents) }\end{array}$ & Brazil & Questionnaire & $\begin{array}{l}\text { To investigate practices } \\
\text { and attitudes of specia- } \\
\text { lized physicians con- } \\
\text { cerning AD diagnosis } \\
\text { disclosure in Brazil }\end{array}$ & $\begin{array}{l}85.6 \% \text { of respondents always used clear terminology such } \\
\text { as dementia or } \mathrm{AD} \text {, and the rest used terms such as } \\
\text { memory impairment, forgetfulness, senility, or sclerosis. }\end{array}$ & $60 \%$ \\
\hline $\begin{array}{l}\text { Sakai \& Carpenter } \\
\text { 2011: } \\
\text { Linguistic features of } \\
\text { power dynamics in } \\
\text { triadic dementia } \\
\text { diagnostic conver- } \\
\text { sations }\end{array}$ & $\begin{array}{l}86 \text { physician-patient- } \\
\text { companion triads }\end{array}$ & $\begin{array}{l}\text { Alzheimer's Dis- } \\
\text { ease Research } \\
\text { Center, USA }\end{array}$ & $\begin{array}{l}\text { Analysis of video- } \\
\text { tapes of diagnosis } \\
\text { disclosure and } \\
\text { questionnaires } \\
\text { completed by } \\
\text { patients and } \\
\text { companions }\end{array}$ & $\begin{array}{l}\text { To explore the expres- } \\
\text { sions of power among } \\
\text { physicians, patients, } \\
\text { and companions during } \\
\text { disclosure. }\end{array}$ & $\begin{array}{l}\text { Physicians dominated the conversations speaking on } \\
\text { average for } 83 \% \text { of the time. Patients spoke for } 10 \% \text { of } \\
\text { the time and companions spoke for } 6 \% \text { of the time. } \\
\text { Companions spoke more when the patient had dementia } \\
\text { than when they did not. } \\
\text { Patients and companions underestimated the time the } \\
\text { physicians spoke and overestimated their total time talking. } \\
\text { Physicians used fewer first-person singular pronouns than } \\
\text { patients and companions. }\end{array}$ & $95 \%$ \\
\hline $\begin{array}{l}\text { Samsi et al., 2014: } \\
\text { Negotiating a labyr- } \\
\text { inth: experiences of } \\
\text { assessment and di- } \\
\text { agnostic journey in } \\
\text { cognitive impair- } \\
\text { ment and dementia }\end{array}$ & $\begin{array}{l}27 \text { people with cog- } \\
\text { nitive impairment } \\
\text { and } 26 \text { carers }\end{array}$ & $\begin{array}{l}\text { Four memory ser- } \\
\text { vices in UK }\end{array}$ & $\begin{array}{l}\text { Interviews before and } \\
\text { after diagnosis } \\
\text { disclosure }\end{array}$ & $\begin{array}{l}\text { To understand the ex- } \\
\text { periences, expectations } \\
\text { and service needs of } \\
\text { people with cognitive } \\
\text { impairment and their } \\
\text { carer along the service } \\
\text { pathway from early } \\
\text { awareness to diagnosis } \\
\text { disclosure. }\end{array}$ & $\begin{array}{l}\text { Many participants in this study felt supported by practi- } \\
\text { tioners at the time and that details of their condition had } \\
\text { been explained to them. } \\
\text { Some participants described feeling shock, loss, grief, and } \\
\text { dejection, and some of these felt that the process of } \\
\text { imparting the diagnosis has increased these feelings. } \\
\text { Participants wanted to know the long-term prognosis but } \\
\text { felt that a staged process of diagnosis disclosure would } \\
\text { have helped them to take the news on board, as they had } \\
\text { little time to discuss concerns and questions. } \\
\text { Carers were keen to talk to the PwD before speaking } \\
\text { further to the practitioner because this interaction } \\
\text { tended to generate further questions. } \\
\text { Participants expressed that they had lacked information } \\
\text { and had only been given basic information, and } \\
\text { practitioners had disregarded their need to know more. } \\
\text { Not all types of dementia were supported, for example, } \\
\text { participants who received a diagnosis of vascular } \\
\text { dementia in this study were discharged without support } \\
\text { from secondary care because they were not eligible for } \\
\text { medication and reported feeling helpless, shocked, lost, } \\
\text { and confused. }\end{array}$ & $60 \%$ \\
\hline
\end{tabular}


Table 1. Continued

\begin{tabular}{|c|c|c|c|c|}
\hline REFERENCE & PARTICIPANTS & SETTING & DESIGN & AIM \\
\hline $\begin{array}{l}\text { Segers 2009: } \\
\text { What Belgian geria- } \\
\text { tricians tell their } \\
\text { patients with AD } \\
\text { and why: a national } \\
\text { survey }\end{array}$ & $\begin{array}{l}88 \text { geriatricians (72 } \\
\text { valid responses; } \\
28.5 \% \text { response } \\
\text { rate of an initial } \\
309 \text { approached) }\end{array}$ & Belgium & $\begin{array}{l}\text { Questionnaire using } \\
\text { open and multiple } \\
\text { choice questions }\end{array}$ & $\begin{array}{l}\text { To understand geriatri- } \\
\text { cians' attitudes toward } \\
\text { disclosure of } \mathrm{AD} \text {, and } \\
\text { whether these opinions } \\
\text { differ from those of } \\
\text { neurologists and neu- } \\
\text { ropsychiatrists. }\end{array}$ \\
\hline
\end{tabular}

Participants who had been assessed and diagnosed in their own homes reported a positive experience, whereas some participants visiting clinics did not.

Participants preferred to use the term memory disease (59\%) over AD (48\%) with PwD but preferred to use $\mathrm{AD}$ with relatives $(87 \%)$.

More than $55 \%$ of participants ask the PwD if they want to know their diagnosis, but only 39\% ask the PwD if they can reveal it to their family. $18 \%$ asked the family if they should reveal the diagnosis to the PwD.

$71 \%$ of participants provided information about the prognosis and progression of $\mathrm{AD}$ to the $\mathrm{PwD}$ and $94 \%$ did to the family. Most cited reasons for not informing PwD of this was that they did not ask (94\%), or the participant was fearful of a depressive reaction (71\%), or that the knowledge was useless to the PwD (29\%)

The most frequent emotional reactions of $\mathrm{PwD}$ on hearing the diagnosis were depressive reaction $(50 \%)$, indifference (51\%), anxiety/nervousness (46.8\%), and denial/ minimization (40\%). The most frequent emotiona reaction from family members was anxiety $(50 \%)$.

Shimizu et al., 2008: 50 carers of PwD and Brazil

Disclosure of the

diagnosis of $\mathrm{AD}$ 50 control partici-

pants who were not carers

Stokes et al., 2014: Understanding the dementia diagnosis: the impact on the caregiving experience

\section{0 spousal carers of The Midlands, PwD recruited \\ England} from local dementia groups and care homes
Semi-structured in- To understand how carterviews using IPA

ing partners make sens
Structured questionnaire interview participants on the disclosure of an $\mathrm{AD}$ diagnosis. of the diagnosis and how it impacts their experiences as caregivers. if they had $\mathrm{AD}$, and $98 \%$ of the controls expressed this wish.

$52 \%$ of carers and $57 \%$ of controls felt that it was the PwD's right to know and ranked this the top justification for disclosure.

Participants wondered why professionals had not been more forthcoming with information and wondered if this was deliberate or accidental. Carers expressed a wish for information about typical manifestations of dementia and practical information about health, social, and financial support.

Some carers were able to use the medical explanation provided as a framework to explain the PwD's behavior and changes. Others found the medical framework incomplete for understanding the condition, and this seemed to occur when there was a lack of explanation of the condition. 
Table 1. Continued

\begin{tabular}{|c|c|c|c|c|c|c|}
\hline REFERENCE & PARTICIPANTS & SETTING & DESIGN & AIM & MAIN FINDINGS & JBI $\%$ \\
\hline $\begin{array}{l}\text { Van-Wijngaarden } \\
\text { et al., 2018: } \\
\text { Entangled in } \\
\text { uncertainty: The } \\
\text { experience of living } \\
\text { with dementia } \\
\text { from the perspec- } \\
\text { tive of family } \\
\text { caregivers }\end{array}$ & $\begin{array}{l}57 \text { carers of PwD } \\
\text { recruited through } \\
\text { research advertise- } \\
\text { ments }\end{array}$ & The Netherlands & $\begin{array}{l}47 \text { semi-structured } \\
\text { interviews and two } \\
\text { focus groups } \\
(\mathrm{N}=6 \text { and } 4)\end{array}$ & $\begin{array}{l}\text { To develop an insight } \\
\text { into what it means to } \\
\text { live with dementia from } \\
\text { the perspective of fa- } \\
\text { mily members. }\end{array}$ & $\begin{array}{l}\text { For most participants, disclosure of the dementia diagnosis } \\
\text { was paradoxical in that it provided relief and an } \\
\text { explanation of the behaviors their loved one had } \\
\text { displayed, but left carers in a state of uncertainty, with no } \\
\text { idea about the course of the disease or expectations for } \\
\text { the future. } \\
\text { Carers receive a new role at the disclosure of the diagnosis, } \\
\text { in an instant they go from not being a carer to being a } \\
\text { carer, but without any education as to what this new role } \\
\text { involves. Many respondents were annoyed at the lack of } \\
\text { information. } \\
\text { Disclosure took away hope and trust in the future for some } \\
\text { participants as they associated dementia with a humi- } \\
\text { liating, progressive process involving poor care, and } \\
\text { social exclusion. } \\
\text { A small minority of carers preferred to receive the } \\
\text { disclosure themselves and not tell the PwD. }\end{array}$ & $80 \%$ \\
\hline $\begin{array}{l}\text { Villars et al., 2010: } \\
\text { The PCP and AD: an } \\
\text { international posi- } \\
\text { tion paper }\end{array}$ & & & $\begin{array}{l}\text { Group opinion of a } \\
\text { panel of expert } \\
\text { neurologists, geria- } \\
\text { tricians, and family } \\
\text { medicine experts } \\
\text { from developed } \\
\text { countries }\end{array}$ & $\begin{array}{l}\text { To establish the role of } \\
\text { the PCP in detection, } \\
\text { early diagnosis, treat- } \\
\text { ment and follow-up, } \\
\text { and in clinical trials of } \\
\text { dementia }\end{array}$ & $\begin{array}{l}\text { The disclosure protocol should be a repeated and planned } \\
\text { announcement where the diagnosis is disclosed by the } \\
\text { specialist, and again by the PCP to reaffirm. } \\
\text { PCPs need training opportunities to integrate this dis- } \\
\text { closure into their consultation. } \\
\text { Disclosure must occur before care planning and provide } \\
\text { basic education to the family. Care plans should be } \\
\text { presented to avoid causing excessive concern to PwD } \\
\text { and families about the progression of dementia. } \\
\text { Legal issues such as advance directives, designated people } \\
\text { of trust, and driving can be covered at this time. }\end{array}$ & $100 \%$ \\
\hline $\begin{array}{l}\text { Vince et al., 2017: } \\
\text { The meaning and } \\
\text { experience of } \\
\text { well-being in } \\
\text { dementia for psy- } \\
\text { chiatrists involved } \\
\text { in diagnostic } \\
\text { disclosure: a } \\
\text { qualitative study }\end{array}$ & 11 psychiatrists & $\begin{array}{l}\text { Three NHS trusts } \\
\text { in the North of } \\
\text { England }\end{array}$ & $\begin{array}{l}\text { Semi-structured in- } \\
\text { terviews with IPA }\end{array}$ & $\begin{array}{l}\text { To explore the meaning } \\
\text { of living well with } \\
\text { dementia from the } \\
\text { perspective of psychia- } \\
\text { trists and their subjec- } \\
\text { tive experiences of } \\
\text { discussing well-being } \\
\text { during diagnostic } \\
\text { disclosure }\end{array}$ & $\begin{array}{l}\text { Participants' understanding of well-being was underpinned } \\
\text { by a nihilistic and reductionist view of dementia, } \\
\text { embedded within the medical model that dementia } \\
\text { represents a threat to well-being directly associated with } \\
\text { a decline in functioning. } \\
\text { Diagnostic disclosure meeting viewed as a key event in a } \\
\text { person's life and an opportunity to discuss well-being } \\
\text { and engagement with services, although some partici- } \\
\text { pants felt the shocking nature of the disclosure meant } \\
\text { that well-being should be addressed at a later time point. }\end{array}$ & $90 \%$ \\
\hline
\end{tabular}


Table 1. Continued

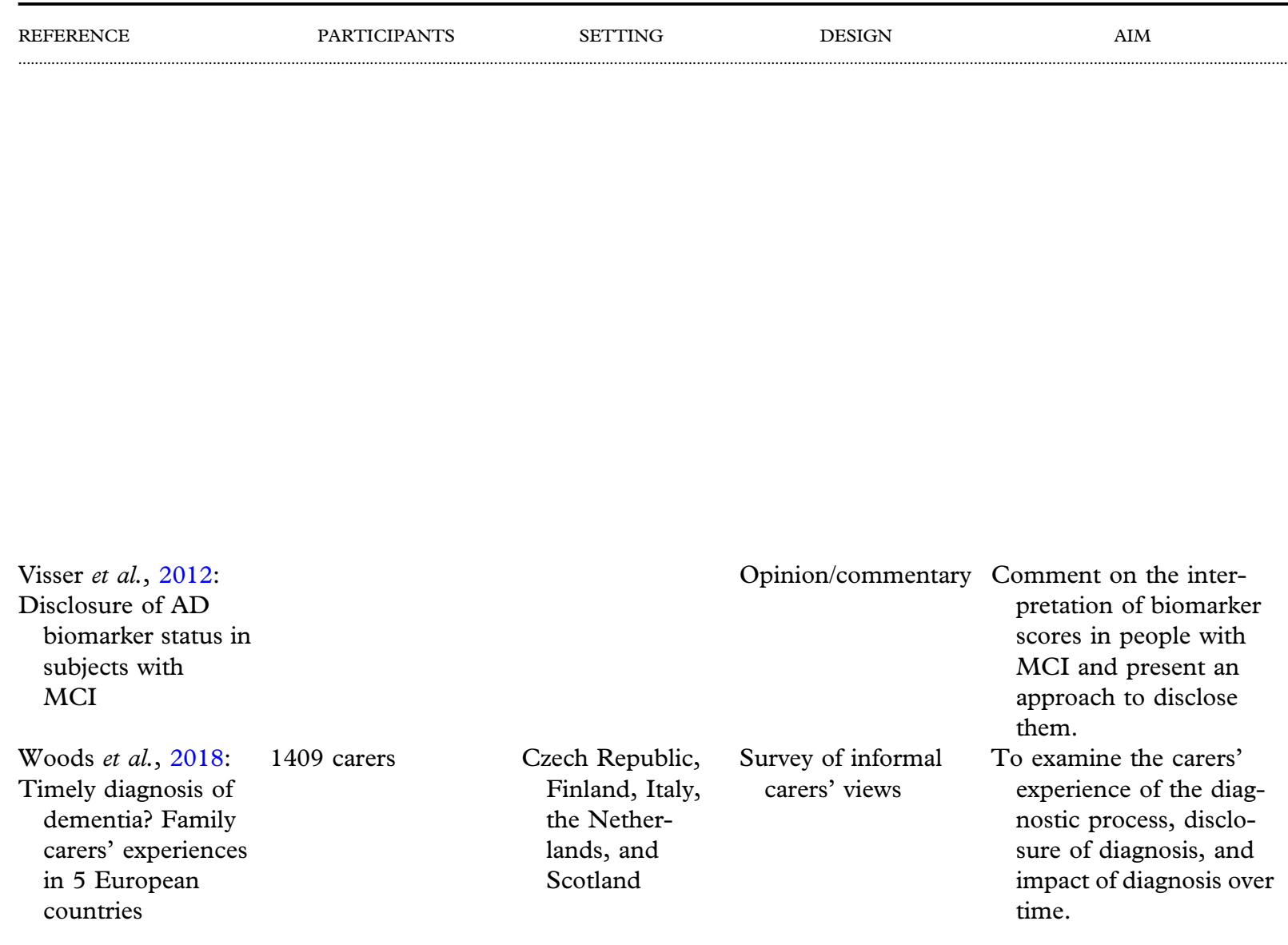
Disclosure is only helpful in supporting well-being if
people are ready to hear their diagnosis, and that early diagnosis can be detrimental to well-being.

Participants felt that it was right to tailor language even though this raised dilemmas for whether to disclose the diagnosis in full and explicit terms.

Participants expressed tensions between positivity and reality, as they wanted to provide positive messages that were genuine and realistic about the future.

Participants felt that the diagnosis was a separate part of the discussion to well-being.

Participants described a discrepancy between the care they wished to provide and the care they did provide, for example, the practical and emotional difficulties of disclosing a diagnosis to someone with whom they do not have a therapeutic relationship.

The authors propose the shared decision-making model. Physicians should provide information on possible outcomes before biomarker testing and agree with patient whether they want to undertake testing and know the results. The implications of different outcomes should be fully explained at disclosure.

$47 \%$ of carers felt the diagnosis was delayed, and contributing factors were the $\mathrm{PwD}$ refusing to be assessed (38\%) and negative professional attitudes (33\%) where the first professional seen did not consider anything wrong and being told there was no point in a diagnosis $(7 \%)$.

Carer ratings of quality indicators of sharing the diagnosis were generally favorable, except for pre-diagnostic counseling (did PwD want to know?), for the carer being able to speak to the healthcare professional alone, and for having a written summary.

Higher-quality diagnosis sharing was associated with lower sadness, depression, and despair, and greater accep-

tance, reassurance both immediately after diagnosis, and beyond (average of 4 years) 
Table 1. Continued

\begin{tabular}{|c|c|c|c|c|c|c|}
\hline REFERENCE & PARTICIPANTS & SETTING & DESIGN & AIM & MAIN FINDINGS & JBI \% \\
\hline $\begin{array}{l}\text { Wynn et al., 2017: } \\
\text { Discourse features } \\
\text { among providers, } \\
\text { patients, and com- } \\
\text { panions, and their } \\
\text { effect on outcomes } \\
\text { of dementia diag- } \\
\text { nosis disclosure }\end{array}$ & $\begin{array}{l}84 \text { PwD-companion } \\
\text { dyads } \\
7 \text { physicians }\end{array}$ & $\begin{array}{l}\text { Memory and } \\
\text { Aging Project } \\
\text { study at } \\
\text { Washington } \\
\text { University, } \\
\text { USA }\end{array}$ & $\begin{array}{l}\text { Videos of diagnostic } \\
\text { feedback sessions } \\
\text { and follow-up } \\
\text { telephone } \\
\text { interviews }\end{array}$ & $\begin{array}{l}\text { To quantify the content } \\
\text { of diagnostic conversa- } \\
\text { tions to examine the } \\
\text { prevalence of different } \\
\text { types of discourse } \\
\text { across stakeholders. } \\
\text { To investigate relation- } \\
\text { ship between elements } \\
\text { of discourse to } \\
\text { dementia } \\
\text { severity and psycholo- } \\
\text { gical outcomes. }\end{array}$ & $\begin{array}{l}\text { With increasing dementia severity, patients spoke less in } \\
\text { the interaction. } \\
\text { Providers (healthcare professionals) spoke most frequently, } \\
\text { accounting for an average of } 73 \% \text { of the dialog. } \\
\text { Patients used lifestyle/psychosocial information and emo- } \\
\text { tional rapport building features of dialog more than } \\
\text { companions. } \\
\text { Providers and companions gave more medical/therapeutic } \\
\text { information as dementia severity increased. } \\
\text { More positive rapport building from providers was } \\
\text { associated with lower depression and anxiety scores for } \\
\text { PwD. }\end{array}$ & $90 \%$ \\
\hline $\begin{array}{l}\text { Xanthopoulou et al., } \\
\text { 2019: Patient and } \\
\text { companion con- } \\
\text { cerns when receiv- } \\
\text { ing a dementia } \\
\text { diagnosis: an ob- } \\
\text { servational study of } \\
\text { dementia diagnosis } \\
\text { feedback meetings }\end{array}$ & $\begin{array}{l}19 \text { healthcare profes- } \\
\text { sionals } \\
60 \text { patients } \\
59 \text { companions }\end{array}$ & UK & $\begin{array}{l}\text { Video observations of } \\
\text { disclosure meet- } \\
\text { ings }\end{array}$ & $\begin{array}{l}\text { This study explored con- } \\
\text { cerns expressed in } \\
\text { HCP-patient- } \\
\text { companion communi- } \\
\text { cation in specialist } \\
\text { memory clinics during } \\
\text { the dementia diagnostic } \\
\text { feedback meeting. }\end{array}$ & $\begin{array}{l}\text { Topics of concern for patients and companions included } \\
\text { the dementia diagnosis itself, symptoms of dementia, } \\
\text { impact on family, physical health of the patient, } \\
\text { frustration with the symptoms of dementia, mental } \\
\text { health, medication, prognosis, the role of the compa- } \\
\text { nion, lack of social connection, and other. All concerns } \\
\text { were given a response by the healthcare professional, } \\
\text { where } 62 \% \text { were encouraged to elaborate and } 38 \% \text { were } \\
\text { discouraged from elaborating. When concerns were } \\
\text { elicited by the healthcare professional, they were more } \\
\text { likely to respond by encouraging elaboration, but } \\
\text { comparatively when concerns were volunteer by the } \\
\text { patient or companion the healthcare professional was } \\
\text { more likely to respond by discouraging elaboration. }\end{array}$ & $100 \%$ \\
\hline $\begin{array}{l}\text { Zaleta et al., 2010: } \\
\text { Patient-centered } \\
\text { communication } \\
\text { during the disclo- } \\
\text { sure of a dementia } \\
\text { diagnosis }\end{array}$ & $\begin{array}{l}54 \text { PwD-compa- } \\
\text { nion-physician } \\
\text { triads } \\
\text { (10 physicians) }\end{array}$ & $\begin{array}{l}\text { Memory and } \\
\text { Aging Project } \\
\text { study at } \\
\text { Washington } \\
\text { University, } \\
\text { USA }\end{array}$ & $\begin{array}{l}\text { Videos of interactions } \\
\text { coded with Roter } \\
\text { Interaction } \\
\text { Analysis System. } \\
\text { Coders concen- } \\
\text { trated on } 15 \\
\text { patient-centered } \\
\text { physician beha- } \\
\text { viors and looked } \\
\text { for expressions of } \\
\text { positive affect. }\end{array}$ & $\begin{array}{l}\text { To characterize the } \\
\text { extent to which physi- } \\
\text { cians adopt a patient- } \\
\text { centered approach in } \\
\text { disclosure. } \\
\text { To evaluate whether } \\
\text { patient-centered beha- } \\
\text { viors differ in relation to } \\
\text { patient characteristics. }\end{array}$ & $\begin{array}{l}\text { The most frequent patient-centered behavior was positive } \\
\text { rapport building, in particular physician agreement with } \\
\text { PwD/companion and showing approval. Facilitation and } \\
\text { patient activation was the next most frequent category of } \\
\text { behaviors, with back-channeling most commonly used } \\
\text { (signaling interest with non-lexical utterances), followed } \\
\text { by checking their understanding, and the PwD/compa- } \\
\text { nion's understanding. Physicians asked for PwD/com- } \\
\text { panion opinions, permission, or reassurance less } \\
\text { frequently. Emotional rapport building was the least } \\
\text { used category of behaviors and occurred infrequently. }\end{array}$ & $80 \%$ \\
\hline
\end{tabular}


Table 1. Continued

\begin{tabular}{|c|c|c|c|c|c|c|}
\hline REFERENCE & PARTICIPANTS & SETTING & DESIGN & AIM & MAIN FINDINGS & JBI $\%$ \\
\hline & & & & & $\begin{array}{l}\text { Physicians rarely offered statements of reassurance or } \\
\text { optimism and infrequently expressed concern or worry. } \\
\text { Few instances of empathy were demonstrated, } \\
\text { PwD/companion feelings were infrequently legitimized, } \\
\text { and physicians tended not to self-disclose or create a } \\
\text { sense of partnership with the PwD/companion. } \\
\text { There was considerable variation between physicians, but } \\
\text { physicians were generally consistent in their behaviors } \\
\text { within themselves. }\end{array}$ & \\
\hline $\begin{array}{l}\text { Zaleta et al., 2012: } \\
\text { Agreement about } \\
\text { diagnosis among } \\
\text { patients, compa- } \\
\text { nions, and profes- } \\
\text { sionals following } \\
\text { a dementia } \\
\text { evaluation }\end{array}$ & $\begin{array}{l}90 \text { PwD-companion } \\
\text { dyads }\end{array}$ & $\begin{array}{l}\text { Memory and } \\
\text { Aging Project } \\
\text { study at } \\
\text { Washington } \\
\text { University, } \\
\text { USA }\end{array}$ & $\begin{array}{l}\text { Video of diagnostic } \\
\text { disclosure. } \\
\text { Diagnostic } \\
\text { impressions } \\
\text { collected from } \\
\text { physician, PwD, } \\
\text { companion, writ- } \\
\text { ten summary from } \\
\text { nurse present at } \\
\text { disclosure, and } \\
\text { trained raters } \\
\text { viewing the video. } \\
\text { PwD and compa- } \\
\text { nions contacted } \\
\text { separately by phone } \\
\text { and asked struc- } \\
\text { tured interview. }\end{array}$ & $\begin{array}{l}\text { To provide a systematic } \\
\text { evaluation of agreement } \\
\text { among physicians, } \\
\text { PwD, companions, } \\
\text { and other professionals } \\
\text { about the results of } \\
\text { diagnostic workup. }\end{array}$ & $\begin{array}{l}\text { Consensus was moderate but far from perfect, and } \\
\text { generally PwD had only fair agreement with other } \\
\text { sources. } \\
\text { PwD and companions felt feedback was thorough, } \\
\text { suggesting self-perceived comprehension was high. } \\
\text { Physicians felt that PwD who agreed with the disclosure } \\
\text { understood the feedback better than those who did not } \\
\text { agree. } \\
\text { PwD tended to report no dementia when other sources } \\
\text { believed they had dementia. }\end{array}$ & $80 \%$ \\
\hline $\begin{array}{l}\text { Zou et al., 2017: } \\
\text { Caregivers' attitude } \\
\text { toward disclosure } \\
\text { of AD diagnosis in } \\
\text { urban China }\end{array}$ & $\begin{array}{l}164 \text { carers of patients } \\
\text { attending memory } \\
\text { outpatients clinic }\end{array}$ & Urban China & $\begin{array}{l}\text { Questionnaire study } \\
\text { of carers of PwD }\end{array}$ & $\begin{array}{l}\text { To obtain the attitude of } \\
\text { carers toward disclo- } \\
\text { sure of AD to patients. }\end{array}$ & $\begin{array}{l}\text { For carers of PwD who knew the diagnosis, half felt the } \\
\text { PwD had suffered emotionally from knowing. } \\
95.7 \% \text { of carers would want to know themselves if they had } \\
\text { dementia. } \\
97.6 \% \text { of carers would want the diagnosis disclosed to a } \\
\text { family member if they had dementia. } \\
\text { Reasons for disclosure included having a right to know, } \\
\text { slowing the disease, facing the condition positively, know } \\
\text { what is happening to them, and plan for the future. }\end{array}$ & $100 \%$ \\
\hline
\end{tabular}


included only the perspectives of HCPs, four studies included only the perspectives of people with dementia, one study included the perspectives of people without a diagnosis of dementia, and seven studies included only the perspectives of carers. Sample sizes ranged from 2 to 1409 . The term "carer" was used in most studies to refer to the individual accompanying the person receiving the diagnosis to the disclosure meeting. Other terms including "relative" and "companion" were also used (Table 1). For brevity, the term "carer" is used in this review.

\section{Setting}

Studies were conducted in clinic and community settings, in the UK (Eccles et al., 2009; Bennett et al., 2018; Hillman, 2017; Innes et al., 2014; Manthorpe et al., 2013; Milby et al., 2017; Page et al., 2015; Peel, 2015; Samsi et al., 2014; Stokes et al., 2014; Vince et al., 2017; Lecouturier et al., 2008; Bailey et al., 2019; McCabe et al., 2019; Xanthopoulou et al., 2019), USA (Burns et al., 2017; Lim et al., 2016; Lingler et al., 2016; Connell et al., 2009; Carpenter et al., 2008; Campbell et al., 2008; Bradford et al., 2011; Grill et al., 2017; Grossberg et al., 2010; Sakai and Carpenter, 2011; Wynn and Carpenter, 2017; Zaleta and Carpenter, 2010; Zaleta et al., 2012; Champlin, 2020), China (Zou et al., 2017), the Netherlands (van Wijngaarden et al., 2018), Brazil (Shimizu et al., 2008; Raicher et al., 2008), Belgium (Segers, 2009; Mormont et al., 2012), Australia (Phillips et al., 2012; Mastwyk et al., 2014; Hansen et al., 2008), Denmark (Nielsen et al., 2018), Ireland (Moore and Cahill, 2013; Foley et al., 2017), Canada (Lee and Weston, 2011), Finland (Laakkonen et al., 2008), Israel (KarnieliMiller et al., 2012), Germany (Kaduszkiewicz et al., 2008), Switzerland (Giezendanner et al., 2018), Japan (Abe et al., 2019), and Malta (Caruana-Pulpan and Scerri, 2014). Three studies used a panEuropean design, involving several countries contributing to data collection (Porteri et al., 2010; Visser et al., 2012; Woods et al., 2019) and one study was international (Villars et al., 2010). The majority of studies were conducted in the UK (12 studies) and the USA (13 studies).

\section{Themes}

\section{Content of the diagnosis disclosure}

In a survey of specialist physicians in Denmark, most respondents reported that they always or often provided information on etiology, progression, and causes of symptoms, and they tailored the information provided depending on the degree of cognitive impairment, specific type of dementia, and level of emotional distress (Nielsen et al., 2018). People with dementia and carers in other studies reported receiving only basic information and felt they lacked information (Samsi et al., 2014), or that nothing was explained (Innes et al., 2014). Messages conveyed should be positive and hopeful, while still being realistic (Vince et al., 2017; Phillips et al., 2012; Lee and Weston, 2011; Lecouturier et al., 2008; Grossberg et al., 2010). People with dementia and carers indicated that they wanted to know more about the future and prognosis (Lecouturier et al., 2008; Laakkonen et al., 2008; Grossberg et al., 2010; Lee and Weston, 2011), sources of support, and local community health and social services (Foley et al., 2017; Innes et al., 2014). The diagnosis disclosure should include information regarding well-being, such as how people with dementia can continue with life as much as possible, maintain their sense of self, and accept their identity as a person with dementia (Vince et al., 2017).

Carers in two studies reported being unsure what to ask in the disclosure meeting (Manthorpe et al., 2013,;Laakkonen et al., 2008) and felt that approaching diagnosis in stages might be preferable to enable people with dementia and carers to absorb and process the information (Laakkonen et al., 2008; Lecouturier et al., 2008). However, in one study, 55\% of respondents reported preferring to receive the whole disclosure up-front (Mastwyk et al., 2014).

The diagnostic process should be structured to ascertain the beliefs, expectations, and potential misconceptions that people with dementia or carers might have. This might include determining what people with dementia already know about dementia (Lee and Weston, 2011) and identifying patientcentered informational needs (Bennett et al., 2018) and may take place in pre-diagnostic counseling ahead of disclosure meetings (Lecouturier et al., 2008).

\section{Emotional impact}

Eighteen studies explored the emotional impact of receiving a diagnosis of dementia. Studies reporting on the emotional impact of the diagnosis on people with dementia suggested they had experienced negative emotions (Zou et al., 2017; McCabe et al., 2019), including feelings of depression (Segers, 2009; Laakkonen et al., 2008), anxiety or nervousness (Segers, 2009; Mormont et al., 2012; Lim et al., 2016), shock (Samsi et al., 2014; Milby et al., 2017; Innes et al., 2014), loss (Samsi et al., 2014), grief (Samsi et al., 2014; Laakkonen et al., 2008), dejection (Samsi et al., 2014), sadness (Mormont et al., 2012), fear (Milby et al., 2017; Phillips et al., 2012), and shame (Kaduszkiewicz et al., 2008). One study 
reported that the diagnosis disclosure also brought satisfaction at receiving an explanation (Mormont et al., 2012). Three studies reported that some people with dementia were either indifferent upon receiving the diagnosis (Segers, 2009), had not experienced significant distress (Zaleta et al., 2012), or showed initial anxiety that was not sustained over time (Burns et al., 2017). A further study reported that anxiety decreased in people with dementia after receiving their diagnosis, particularly for those with high anxiety prior to the diagnosis (Carpenter et al., 2008). Studies on the perspectives of HCPs suggested that some people with dementia deny or minimize the diagnosis (Segers, 2009; Kaduszkiewicz et al., 2008). Studies exploring the perspectives of carers or family members found they reported feeling anxious (Segers, 2009; Laakkonen et al., 2008), uncertain (van Wijngaarden et al., 2018; Laakkonen et al., 2008), hopeless (Laakkonen et al., 2008), lonely (Laakkonen et al., 2008), that their hope and trust in the future was taken away (van Wijngaarden et al., 2018), and anxiety and uncertainty due to not knowing where to get help or what to do next (Laakkonen et al., 2008). One study found that carers reported a sense of relief and validation that their observations about something being wrong were correct, which in turn led to a sense of acceptance. However, this study also found that carers felt sad, terrified, overwhelmed, and worried (Champlin, 2020). HCPs reported feeling a need to manage their own emotional journey (Bennett et al., 2018). General practitioner (GPs) reported a sense of trepidation regarding the disclosure (Phillips et al., 2012) and were hesitant and expressed worry regarding the negative psychological impact upon people with dementia of the diagnosis disclosure due to stigma (Abe et al., 2019).

\section{Communication of the diagnosis}

Communication was explored in 21 studies. There were conflicting findings regarding using explicit terms such as "dementia" or specific labels like "Alzheimer's disease" when communicating the diagnosis to people with dementia and carers. Five studies reported that such terminology should be used (Bennett et al., 2018; Grossberg et al., 2010) and was commonly used (Raicher et al., 2008; Nielsen et al., 2018; Bailey et al., 2019), but eight reported that HCPs tended not to use these terms (Zou et al., 2017; Zaleta et al., 2012; Segers, 2009; Phillips et al., 2012; Moore and Cahill, 2013; Milby et al., 2017; Kaduszkiewicz et al., 2008; Hansen et al., 2008). Reasons for not using specific terminology were that ambiguous language may be preferable when HCPs themselves are uncertain of the diagnosis (Zaleta et al., 2012; Milby et al., 2017), and unambiguous terms were not always helpful in facilitating the person with dementia's understanding (Peel, 2015). Other reasons included minimizing distress (Milby et al., 2017; Bailey et al., 2019), avoiding negative connotations of the word "dementia" (Phillips et al., 2012), and avoiding pathologizing the condition (Abe et al., 2019). Cultural differences were highlighted, suggesting that colloquial terms were used because they were more familiar to the local community (Abe et al., 2019).

Considering communication patterns in consultations, one study found that HCPs tended to dominate the disclosure meeting by talking on average for $83 \%$ of the time. Emphasis shifted from the person with dementia to the carer even when the person with dementia was in the mild stages of the condition and still able to speak and contribute information (Wynn and Carpenter, 2017). While patient-centered communication was noted in one study, findings suggested that aspects of communication such as emotional rapport building were infrequent (Zaleta and Carpenter, 2010). Three studies indicated that written information should accompany disclosure meetings (Nielsen et al., 2018; Mastwyk et al., 2014; Grossberg et al., 2010).

\section{People involved}

There were mixed findings regarding who should disclose the diagnosis. One study suggested specialists should always take this role (Villars et al., 2010) with another suggesting that specialists could occupy a position of blame in contrast to the GP, who could provide support to patients (Phillips et al., 2012). However, this study also reported that GPs should take on the role of disclosure when a welldeveloped patient-doctor relationship existed because they would be known to the patient compared to a specialist. A Swiss survey reported that $75 \%$ of GPs disclosed the diagnosis themselves (Giezendanner et al., 2018). Other professionals have roles in disclosure, suggesting that discussing well-being should be undertaken by a multidisciplinary team (Vince et al., 2017), although psychiatrists wanted more time to discuss well-being during the disclosure to avoid being seen as someone who only diagnoses conditions and prescribes medication (Vince et al., 2017).

The majority of papers agreed it was beneficial for carers to accompany the person with dementia to disclosure meetings (Phillips et al., 2012; Page et al., 2015; Nielsen et al., 2018; Grossberg et al., 2010; Bradford et al., 2011; Lingler et al., 2016; Abe et al., 2019; Bailey et al., 2019; Giezendanner et al., 2018). Family members often wanted more information and could receive education to help them cope in the future (Phillips et al., 2012; Bailey et al., 2019). 
Carers represent a reassuring presence for the HCP (Page et al., 2015), can help them communicate the diagnosis more effectively to the person with dementia (Grossberg et al., 2010), and help to recall details of the diagnosis (Bradford et al., 2011; Bailey et al., 2019). One study found that, within its sample, people with MCI showed a lack of health literacy, suggesting carers were necessary to help process and understand the information provided (Lingler et al., 2016). Further, one study suggested that carers are usually most troubled by symptoms of dementia, and using disclosure meetings to reassure them is important (Abe et al., 2019). HCPs in one study suggested that fuller details of the diagnosis were disclosed to carers rather than people with dementia (Kaduszkiewicz et al., 2008). A key point here is the lack of people with dementia as participants in the included studies, which limits the ability to draw conclusions regarding their preferences for their own and others' involvement.

\section{Attitudes toward diagnosis disclosure}

Studies investigating HCPs' attitudes toward disclosing the diagnosis found it can be perceived as draining (Milby et al., 2017); they might feel like the "grim reaper" when delivering bad news (Bennett et al., 2018) or worry that the process could ruin doctor-patient relationships (Kaduszkiewicz et al., 2008). Some psychiatrists may hold a medically rooted nihilistic and reductionist attitude due to a sense of hopelessness around potential interventions for people with dementia and a lack of appropriate services to support well-being (Vince et al., 2017). Geriatricians who did not provide information on progression and prognosis of Alzheimer's disease to the person with dementia reported this was because the person with dementia did not ask, or the HCP was either fearful of a depressive reaction or felt the knowledge was of no use (Segers, 2009).

Carers typically approached diagnosis disclosure as a useful event (Mormont et al., 2012) and felt that people with dementia had a right to know in order to begin treatment, face the condition positively, know what is happening to them, and plan for the future (Zou et al., 2017). Carers were divided on whether the diagnosis should be revealed in an up-front approach, or in stages (Mastwyk et al., 2014). Those who preferred an up-front approach felt it necessary for planning and managing issues such as driving cessation. Carers felt empowered when HCPs explained how and where to get treatment (Mastwyk et al., 2014) and tended to prefer the HCP openly informing the person with dementia of the diagnosis (Laakkonen et al., 2008). A good quality disclosure was associated with better carer adjustment in relation to sadness, depression, and acceptance (Woods et al., 2018).

Only two studies considered attitudes toward diagnosis disclosure from the perspective of people with dementia themselves, with one finding that people with dementia tended not to agree with or acknowledge the information disclosed by the HCP (Peel, 2015). The other study found that people with dementia would prefer to receive a direct disclosure even though it might be a shock (Mastwyk et al., 2014).

\section{Use of diagnostic tests and assessments}

Four studies suggest that, prior to the disclosure meeting, HCPs should discuss what people with dementia and carers can expect from assessments, especially from brain scans and biomarker testing, and potential limitations or implications of diagnostic tests (Visser et al., 2012; Porteri et al., 2010; Grill et al., 2017; Lingler et al., 2016). People with dementia and carers should have the choice to receive the results from assessments or not and should have the opportunity to change their mind at any point (Porteri et al., 2010).

Three studies suggested that brain scans should be reviewed in disclosure meetings (Nielsen et al., 2018; Lingler et al., 2016; Grill et al., 2017), so people with dementia and carers can see the images. Two studies offered caution regarding how results of amyloid scans were communicated, where explanations should state that presence of amyloid indicates a risk for developing dementia while absence of amyloid does not indicate absence of illness (Grill et al., 2017), and that biomarkers are not yet a diagnostic tool in themselves (Burns et al., 2017). One study advocated for provision of take-home materials to supplement the explanation of scans and assessments (Lingler et al., 2016).

\section{Truth telling and deception}

Three studies considered the aspect of truth telling or withholding the truth of the diagnosis from people with dementia. One study reported that HCPs felt a truthful diagnosis was not necessary due to a lack of effective treatments and potential impact on preexisting symptoms of anxiety or depression (Porteri et al., 2010). Conversely, a different study found that providing a truthful diagnosis did not create a negative emotional impact for people with dementia or carers and instead helped to relieve anxiety or depression for both (Carpenter et al., 2008). The third study reported difficulties in delivering the diagnosis as people with dementia may try to normalize their experience, and HCPs must balance this with not 
deceiving the person with dementia as to the diagnosis (Peel, 2015).

\section{Timeliness}

Three studies considered the timing of receiving a diagnosis of dementia, with one study reporting that nearly half of carers surveyed across five European countries felt diagnosis was delayed (Woods et al., 2018). Reasons for delay included people with dementia refusing to be assessed, negative professional attitudes, and being told there was no point in a diagnosis. Receiving timely diagnoses could assist people with dementia in remembering their diagnosis (Bradford et al., 2011), but another study indicated potential detriment to well-being if provided before a person had processed what is happening and accepted the changes they are experiencing (Vince et al., 2017).

\section{Training and skills}

As far as can be determined from the included studies, there is no specific training available in how to disclose a diagnosis of dementia. In two studies, HCPs reported receiving training in breaking bad news, attending conferences on the topic, or using general guidelines for diagnostic disclosure (Vince et al., 2017; Nielsen et al., 2018). Despite disclosure often being performed by specialists, two studies indicated that PCPs should have training on disclosing sensitively (Foley et al., 2017) and integrating disclosure into their consultations (Villars et al., 2010).

\section{Discussion}

This review provides the only up-to-date comprehensive account, based on a rigorous systematic literature search, of common practice around the world in disclosing a diagnosis of dementia from the perspectives of people with dementia, carers, and HCPs. These findings suggest that telling the person with dementia the diagnosis is now common practice. However, HCPs may experience discomfort in revealing the diagnosis and consequently use euphemisms to describe the syndrome rather than explicit terminology. Generally, if diagnosis disclosure is provided as a one-off event, and without discussion of hopeful aspects or emotional rapport building, it has a negative impact on people with dementia and carers. Carers report needing to know more about the future and prognosis, and their preference is for the diagnosis to be disclosed in a realistic yet hopeful way. HCPs would benefit from guidance and support in how to disclose the diagnosis, and the disclosure should be approached as a process involving a multidisciplinary team rather than as a singular event. The findings suggest progress in normalizing the diagnosis and reducing stigma but highlight that there is still more to be done.

Disclosure was viewed as a negative process by HCPs who reported an attitude of hopelessness, and uncertainty around the exact diagnosis, prognosis, and how much people receiving the diagnosis already knows or can understand. HCPs highlighted that the information needed by people with dementia and carers is difficult to deliver due to the delicate balance between honesty and hope (Bailey et al., 2016). HCPs do not appear comfortable with their position as someone who delivers bad news and can only provide limited treatment options. This review also identified that little consideration was given to patient-centered communication and expectations extending to cultural differences.

Our findings suggest that disclosures can cause people with dementia to suffer emotionally (Zou et al., 2017). Similarly, emotional rapport building is identified as important yet may not be frequently used in disclosures (Zaleta and Carpenter, 2010), suggesting that HCPs are not prioritizing the emotional impact of receiving a diagnosis as a key consequence of the meeting. While disclosure tended to have a negative impact for people with dementia and their carers, carers did report that disclosure was a useful event that enabled them to organize treatment and support, and discussion of etiology, progression, and causes was helpful. However, carers expressed a need to know more about the future and prognosis following diagnosis. This finding shows consistency with a previous review (Werner et al., 2013), but the present review shows a step forward in the dialog around truth telling, in that simply knowing the diagnosis itself is not enough. Carers need to know what will happen to the person with dementia in the future, beyond the diagnosis, and what ramifications this will have for themselves as carers.

Consistent with earlier reviews (Lecouturier et al., 2008; Werner et al., 2013) is the preference for a process approach to disclosure. This is supported by guidance from the UK Alzheimer's Society (Alzheimer's Society, 2018) and the British Psychological Society (Watts et al., 2018) which suggest that delivering information in one session is overwhelming and instead disclosure should be embedded within the care pathway. People with dementia and carers need more time and space to process information provided in the disclosure, which could be achieved using follow-up appointments. Using follow-up appointments could aid with retaining information, as in the general population $34-88 \%$ of what is said in medical appointments is forgotten, depending on the type of 
information provided, where general recall is higher for a discussion, but lower for specific information such as regarding lifestyle interventions (Richard et al., 2017). This is important, given the range of topics covered in a diagnosis disclosure, and it is likely that this figure is higher for people experiencing cognitive changes. More opportunities to impart the same information, or presenting smaller amounts of information more than once, could help people remember the diagnosis and its implications, while providing space to explore the emotional impact of the diagnosis. However, it must be noted that increasing the number of appointments would require greater resources, without which an increase in waiting times is likely and this is not desirable either. Involving other agencies, such as third sector agencies, could be useful.

\section{Strengths and limitations}

This review used a comprehensive search strategy across several databases to identify as many relevant papers as possible, although some papers indexed in other databases may have been missed. The rigor of the systematic search and quality review can be seen in that searching was completed by two reviewers, allowing for discussion and justification for inclusion or exclusion of each paper, and a sample of papers were assessed for quality by a third, independent reviewer which resulted in a high level of agreement. Quality assessment was not used in previous reviews of this topic area (Werner et al., 2013), and showing how this review has moved the discussion forward by highlighting methodological issues that must be considered in future work. Despite studies being of a variety of designs and conducted in different settings, the findings are generally consistent, suggesting that this review has identified realistic trends. The perspectives of people with dementia, carers, and HCPs were captured in this review, ensuring that findings are relevant to the experience of all people involved in the disclosure, and any implications can consider each set of needs.

Only studies written in English were included, and therefore some findings may have been missed. However, studies from across the world were included and despite some contradictory findings, generally there was agreement, suggesting that studies in languages other than English may not have significantly changed the results if included. Studies of all designs were included and, although this renders it impossible to synthesize numerical findings into meaningful quantitative analyses, the integration of qualitative and quantitative findings should be considered a strength. One methodological consideration to acknowledge is that much of the research included in this review is reliant on self-report techniques, either through use of surveys or qualitative interviews. While surveys can reach a broad audience, and interviews can elicit rich details about the experience of disclosure, both methods of data collection can be affected by bias, and it is challenging to reliably compare or contrast practices reported by HCPs with the impact they have on recipients (Plejert et al., 2017). Only 8 of the 52 included studies used observational methods (Hillman, 2017; McCabe et al., 2019; Peel, 2015; Sakai and Carpenter, 2011; Wynn and Carpenter, 2017; Xanthopoulou et al., 2019; Zaleta and Carpenter, 2010; Zaleta et al., 2012).

\section{Implications}

ReCommendations FOR CLINICAL PRACTICE Communication skills do not reliably improve with experience alone (Cantwell and Ramirez, 1997) and consequently further training, supervision, and regular reflection on practice may support HCPs in navigating uncertainties and managing their own emotional journey. For HCPs in specialist roles, training should be specific to disclosing a diagnosis of dementia rather than generally about breaking bad news, and supervision should cover managing the emotions of the person with dementia and the carer, as well as their own emotional responses. Communication skills training is mandatory in the majority of training programs for all HCPs (Moore et al., 2018), but training to develop skills in shared communication, to raise awareness of supporting people with dementia and carers to assert themselves and maintain their agency and power during the disclosure, is needed. HCPs may benefit from guidance in understanding and supporting cultural differences and sensitivities in diagnosis disclosure. However, it is recognized that training is resourceintensive and relies upon having appropriately trained individuals who are available to train and support others. This is likely to be difficult across disciplines and in time-pressured healthcare environments.

Pre-diagnostic counseling prior to disclosure could explore beliefs and expectations and potentially mitigate negative impacts by ensuring people with dementia and carers are prepared. This may support people with dementia and carers to consider questions they could ask between meetings and provide greater opportunity to speak during disclosure meetings. Follow-up meetings could enable tailoring of information, an opportunity to reconfirm the diagnosis, and discussions of prognosis, future considerations, and access to local support. Involving multidisciplinary teams could help to provide an holistic and hopeful disclosure, reducing the negative emotional burden on individual HCPs 
while also reducing the likelihood that the disclosure is viewed as a singular negative event by people with dementia and carers (Vince et al., 2017). Reassurance and a realistic sense of hope about the future should be emphasized throughout, and HCPs could discuss how people with dementia and their carers can maintain quality of life after diagnosis.

RECOMMENDATIONS FOR PEOPLE WITH DEMENTIA AND CARERS

Information about memory assessments and what typically happens could be provided through channels including posters or leaflets in GP surgeries and community spaces. Information about what to expect when receiving the results of assessments may be provided ahead of disclosure meetings, although this could be distressing if information were given without having someone available to provide support or further explanations. People with dementia should be supported to ensure they can have someone attend the disclosure meeting with them if they wish. Encouraging people with dementia to arrange a follow-up appointment with their GP could be beneficial for asking further questions and considering the future implications.

\section{RECOMMENDATIONS FOR RESEARCH}

Much of the research included in this review relies on recalling the disclosure experience, and there is disparity between viewpoints of people with dementia, carers, and HCPs. A sensible next step is to conduct research that directly observes disclosure meetings, considering all individuals involved. While work in this area has already been undertaken involving people with dementia, carers, and HCPs (Peel, 2015), further work currently underway focuses on doctors only (Bailey et al., 2019; Xanthopoulou et al., 2019). More research that considers the three-way dialog between people with dementia, carers, and HCPs, analyzing what each brings to the disclosure and what each takes away, is needed. Most research to date is from the perspective of carers, with some from the perspective of HCPs. More research considering perspectives of people with dementia on diagnosis disclosure is needed to fully understand their wants and needs. Research combining all three perspectives is required to develop a realistic understanding of how disclosures can be best conducted to benefit everyone involved, more closely reflecting real practice.

Researchers must respect the agency and rights of people with dementia to participate in research. Earlier reviews (Werner et al., 2013; Lecouturier et al., 2008) have not explored power dynamics between individuals involved in disclosures, or the agency that people with dementia possess in the interaction. Only two studies in this review specifically considered attitudes toward diagnosis disclosure from the perspective of the person with dementia, although other studies have explored difference facets of the disclosure process. Less than half of the studies in this review recruited people with dementia, and of those that did, the number of participants with dementia was small. Developing an understanding of disclosure without involving people with dementia is inconsistent with patient-centered care. The lack of information regarding cultural differences in disclosure clearly shows that future research must explore this area to develop practices that support a culturally sensitive disclosure process.

Future qualitative studies could demonstrate greater methodological quality by stating the underpinning philosophical perspective adopted by researchers during data collection and analysis, including reflexive statements to locate researchers culturally and theoretically. Increased awareness by journal editors and peer reviewers regarding the reporting of qualitative methodology would encourage researchers to be transparent in their theoretical approaches.

\section{Conclusions}

Disclosing a diagnosis of dementia is a key process for people with dementia, carers, and HCPs. This review indicates that while changes in some aspects of disclosure have occurred over the last decade, disclosing a diagnosis of dementia remains a difficult and complex process, for which formal training and guidance is lacking. Receiving a diagnosis is generally a negative process for people with dementia, carers, and HCPs and leaves carers in particular feeling uncertain over the prognosis and future of the person they care for. Pre-diagnostic counseling and follow-up appointments could enable realistic and hopeful discussions of the implications of receiving a diagnosis of dementia, while reducing emotional burden on HCPs. This review highlights a need for more objective evidence that considers the perspectives of all individuals involved.

\section{Conflict of interests}

None.

\section{Author contributions}

JY and MS conducted the systematic review and the quality analyses of the included articles. JY wrote the article and MS, RS and LC all contributed to writing the article. All authors designed the review. 


\section{Acknowledgments}

The authors would like to thank Alexander Humm (AH) for assisting with the quality review process.

\section{References}

Abe, M., Tsunawaki, S., Matsuda, M., Cigolle, C. T., Fetters, M. D. and Inoue, M. (2019). Perspectives on disclosure of the dementia diagnosis among primary care physicians in Japan: a qualitatively driven mixed methods study. BMC Family Practice, 20, 69.

Abhayaratne, C., Blanchard, E., Cartwright, V. and Greally, S. 2019. MSNAP Fifth National Report. London Royal College of Psychiatrists.

Alzheimer's Society. 2018. Assessment and diagnosis: Factsheet 426LP. London: Alzheimer's Society.

Aromataris, E. and Munn, Z. (Eds.), (2017) Foanna Briggs Institute Reviewer's Manual. The Joanna Briggs Institute.

Bailey, C., Dooley, J. and Mccabe, R. (2016). The Little Dance: Delicate Deliveries of Dementia Diagnoses: Emerging findings from the ShareD study focus groups with doctors. Royal College of Psychiatrists Old Age Faculty Scientific Meeting, March 9-11 2016 Nottingham, UK.

Bailey, C., Dooley, J. and Mccabe, R. (2019). 'How do they want to know?' Doctors' perspectives on making and communicating a diagnosis of dementia. DementiaInternational Fournal of Social Research and Practice, 18, 3004-3022.

Bennett, C. E., De Boos, D. and Moghaddam, N. G. (2018). Developing a tool to support diagnostic delivery of dementia. Dementia (London), 1471301217750936.

Bradford, A. et al. (2011). Knowledge of documented dementia diagnosis and treatment in veterans and their caregivers. American fournal of Alzheimers Disease and Other Dementias, 26, 127-133.

Bunn, F. et al. (2012). Psychosocial factors that shape patient and carer experiences of dementia diagnosis and treatment: a systematic review of qualitative studies. PLoS Medicine, 9, e1001331.

Burns, J. M., Johnson, D. K., Liebmann, E. P., Bothwell, R. J., Morris, J. K. and Vidoni, E. D. (2017). Safety of disclosing amyloid status in cognitively normal older adults. Alzheimer's \& Dementia, 13, 1024-1030.

Campbell, K. H., Stocking, C. B., Hougham, G. W., Whitehouse, P. J., Danner, D. D. and Sachs, G. A. (2008). Dementia, diagnostic disclosure, and self-reported health status. Fournal of the American Geriatrics Society, 56, 296-300.

Cantwell, B. and Ramirez, A. J. (1997). Doctor-patient communication: a study of junior house officers. Medical Education, 31, 17-21.

Carpenter, B. D. et al. (2008). Reaction to a dementia diagnosis in individuals with Alzheimer's disease and mild cognitive impairment. Fournal of the American Geriatrics Society, 56, 405-412.

Caruana-Pulpan, O. and Scerri, C. (2014). Practices in diagnosis, disclosure and pharmacotherapeutic management of dementia by general practitioners - a national survey. Aging \& Mental Health, 18, 179-186.
Champlin, B. E. (2020). The informal caregiver's lived experience of being present with a patient who receives a diagnosis of dementia: a phenomenological inquiry. Dementia-International Fournal of Social Research and Practice, 19, 375-396.

Chrisp, T. A., Thomas, B. D., Goddard, W. A. and Owens, A. (2011). Dementia timeline: journeys, delays and decisions on the pathway to an early diagnosis. Dementia, $10,555-570$.

Connell, C. M., Roberts, J. S., Mclaughlin, S. J. and Carpenter, B. D. (2009). Black and white adult family members' attitudes toward a dementia diagnosis. Fournal of the American Geriatrics Society, 57, 1562-1568.

Department of Health (2015). Prime Minister's challenge on dementia 2020. London: Department of Health.

Dooley, J., Bailey, C. and Mccabe, R. (2015). Communication in healthcare interactions in dementia: a systematic review of observational studies. International Psychogeriatrics, 27, 1277-1300.

Eccles, M. P. et al. (2009). Improving professional practice in the disclosure of a diagnosis of dementia: a modeling experiment to evaluate a theory-based intervention. International fournal of Behavioral Medicine, 16, 377-387.

Foley, T., Boyle, S., Jennings, A. and Smithson, W. H. (2017). "We're certainly not in our comfort zone": a qualitative study of GPs' dementia-care educational needs. BMC Family Practice, 18, 66.

Giezendanner, S. et al. (2018). Early diagnosis and management of dementia in general practice - how do Swiss GPs meet the challenge? Swiss Medical Weekly, 148, w14695.

Grill, J. D. et al. (2017). Communicating mild cognitive impairment diagnoses with and without amyloid imaging. Alzheimers Research E Therapy, 9, 35.

Grossberg, G. T., Christensen, D. D., Griffith, P. A., Kerwin, D. R., Hunt, G. and Hall, E. J. (2010). The art of sharing the diagnosis and management of Alzheimer's disease with patients and caregivers: recommendations of an expert consensus panel. Primary Care Companion to the fournal of Clinical Psychiatry, 12.

Hansen, E. C., Hughes, C., Routley, G. and Robinson, A. L. (2008). General practitioners' experiences and understandings of diagnosing dementia: factors impacting on early diagnosis. Social Science $\mathcal{E}$ Medicine, 67, 1776-1783.

Hillman, A. (2017). Diagnosing dementia: ethnography, interactional ethics and everyday moral reasoning. Social Theory \& Health, 15, 44-65.

Innes, A., Szymczynska, P. and Stark, C. (2014). Dementia diagnosis and post-diagnostic support in Scottish rural communities: experiences of people with dementia and their families. Dementia, 13, 233-247.

Kaduszkiewicz, H., Bachmann, C. and Van den Bussche, H. (2008). Telling 'the truth' in dementia-Do attitude and approach of general practitioners and specialists differ? Patient Education E Counseling, 70, 220-226.

Karnieli-Miller, O. et al. (2012). Expectations, experiences, and tensions in the memory clinic: the process of diagnosis disclosure of dementia within a triad. International Psychogeriatrics, 24, 1756-1770. 
Laakkonen, M. L. et al. (2008). How do elderly spouse care givers of people with Alzheimer disease experience the disclosure of dementia diagnosis and subsequent care? Fournal of Medical Ethics, 34, 427-430.

Lecouturier, J. et al. (2008). Appropriate disclosure of a diagnosis of dementia: identifying the key behaviours of 'best practice'. BMC Health Services Research, 8, 95.

Lee, L. and Weston, W. W. (2011). Disclosing a diagnosis of dementia: helping learners to break bad news. Canadian Family Physician, 57, 851-852, e270-2.

Lim, Y. Y., Maruff, P., Getter, C. and Snyder, P. J. (2016). Disclosure of positron emission tomography amyloid imaging results: a preliminary study of safety and tolerability. Alzheimer's E Dementia, 12, 454-458.

Lingler, J. H. et al. (2016). Development of a standardized approach to disclosing amyloid imaging research results in mild cognitive impairment. Fournal of Alzheimer's Disease, $52,17-24$.

Manthorpe, J. et al. (2013). From forgetfulness to dementia: clinical and commissioning implications of diagnostic experiences. British fournal of General Practice, 63, 69-75.

Mastwyk, M., Ames, D., Ellis, K. A., Chiu, E. and Dow, B. (2014). Disclosing a dementia diagnosis: what do patients and family consider important? International Psychogeriatrics, 26, 1263-1272.

Mccabe, R., Pavlickova, H., Xanthopoulou, P., Bass, N. J., Livingston, G. and Dooley, J. (2019). Patient and companion shared decision making and satisfaction with decisions about starting cholinesterase medication at dementia diagnosis. Age and Ageing, 48, 706-713.

Milby, E., Murphy, G. and Winthrop, A. (2017). Diagnosis disclosure in dementia: Understanding the experiences of clinicians and patients who have recently given or received a diagnosis. Dementia (London), 16, 611-628.

Moore, P. M., Rivera, S., Bravo-Soto, G. A., Olivares, C. and Lawrie, T. A. (2018). Communication skills training for healthcare professionals working with people who have cancer. The Cochrane Database of Systematic Reviews, 7, CD003751-CD003751.

Moore, V. and Cahill, S. (2013). Diagnosis and disclosure of dementia - A comparative qualitative study of Irish and Swedish General Practitioners. Aging \& Mental Health, 17, $77-84$.

Mormont, E., de Fays, K. and Jamart, J. (2012). Experiences of the patients and their caregivers regarding the disclosure of the diagnosis of Alzheimer's disease: a Belgian retrospective survey. Acta Neurologica Belgica, 112, 249-254.

Nielsen, T. R., et al. (2018). The process of disclosing a diagnosis of dementia and mild cognitive impairment: a national survey of specialist physicians in Denmark. Dementia (London), 1471301218777443.

Page, S., Davies-Abbott, I., Ingley, S. and Bee, P. (2015). 'Rydym Eisiau Gwybod'-the dementia diagnosis disclosure preferences of people in North Wales. International fournal of Geriatric Psychiatry, 30, 108-110.

Peel, E. (2015). Diagnostic communication in the memory clinic: a conversation analytic perspective. Aging $\mathcal{E}$ Mental Health, 19, 1123-1130.
Phillips, J. et al. (2012). Difficulties in disclosing the diagnosis of dementia: a qualitative study in general practice. The British fournal of General Practice, 62, e546-e553.

Plejert, C., Jones, D. and Peel, E. (2017). Life with Dementia: Relations, Responses and Agency in Everyday Life. Life with Dementia: Relations, Responses and Agency in Everyday Life. London: Palgrave Macmillan.

Porteri, C., Galluzzi, S., Geroldi, C. and Frisoni, G. B. (2010). Diagnosis disclosure of prodromal Alzheimer disease-ethical analysis of two cases. The Canadian fournal of Neurological Sciences, 37, 67-75.

Raicher, I. et al. (2008). Alzheimer's disease diagnosis disclosure in Brazil: a survey of specialized physicians' current practice and attitudes. International Psychogeriatrics, 20, 471-481.

Richard, C., Glaser, E. and Lussier, M. T. (2017). Communication and patient participation influencing patient recall of treatment discussions. Health Expectations, 20, 760-770.

Robinson, L. et al. (2011). The transition to dementiaindividual and family experiences of receiving a diagnosis: a review. International Psychogeriatrics, 23, 1026-1043.

Robinson, L., Tang, E. and Taylor, J.-P. (2015). Dementia: timely diagnosis and early intervention. $B M \mathcal{F}$, 350, h3029.

Sakai, E. Y. and Carpenter, B. D. (2011). Linguistic features of power dynamics in triadic dementia diagnostic conversations. Patient Education and Counseling, 85, 295-298.

Samsi, K. et al. (2014). Negotiating a labyrinth: experiences of assessment and diagnostic journey in cognitive impairment and dementia. International fournal of Geriatric Psychiatry, 29, 58-67.

Segers, K. (2009). What Belgian geriatricians tell their patients with Alzheimer's disease and why: a national survey. Acta Neurologica Belgica, 109, 283-293.

Shimizu, M. M., Raicher, I., Takahashi, D. Y., Caramelli, P. and Nitrini, R. (2008). Disclosure of the diagnosis of Alzheimer's disease: caregivers' opinions in a Brazilian sample. Arquivos de Neuropsiquiatria, 66, 625-630.

Stokes, L. A., Combes, H. and Stokes, G. (2014). Understanding the dementia diagnosis: the impact on the caregiving experience. Dementia (London), 13, 59-78.

van den Dungen, P. et al. (2014). Preferences regarding disclosure of a diagnosis of dementia: a systematic review. International Psychogeriatrics, 26, 1603-1618.

van Wijngaarden, E., van der Wedden, H., Henning, Z., Komen, R. and The, A. M. (2018). Entangled in uncertainty: the experience of living with dementia from the perspective of family caregivers. PLoS One, 13, e0198034.

Villars, H. et al. (2010). The primary care physician and Alzheimer's disease: an international position paper. The Fournal of Nutrition, Health $\&$ Aging, 14, 110-120.

Vince, A., Clarke, C. and Wolverson, E. L. (2017). The meaning and experience of well-being in dementia for psychiatrists involved in diagnostic disclosure: a qualitative study. International Psychogeriatrics, 29, 93-104. 
Visser, P. J., Wolf, H., Frisoni, G. and Gertz, H.-J. (2012). Disclosure of Alzheimer's disease biomarker status in subjects with mild cognitive impairment. Biomarkers in Medicine, 6, 365-368.

Watts, S., Mccabe, R. and Guss, G. (2018). Communicating a diagnosis of dementia. Leicester: The British Psychological Society.

Werner, P., Karnieli-Miller, O. and Eidelman, S. (2013). Current knowledge and future directions about the disclosure of dementia: a systematic review of the first decade of the 21st century. Alzheimers $\&$ Dementia, 9, e74-88.

Woods, B. et al. (2018). Timely diagnosis of dementia? Family carers' experiences in 5 European countries. International fournal of Geriatric Psychiatry. 34, 114-121.

Woods, B. et al. (2019). Timely diagnosis of dementia? Family carers' experiences in 5 European countries. International Fournal of Geriatric Psychiatry, 34, 114-121.

World Health Organization. (2020). Dementia Fact Sheet [Online]. World Health Organization. Available at: https:// www.who.int/news-room/fact-sheets/detail/dementia; accessed 4 March 2020.
Wynn, M. J. and Carpenter, B. D. (2017). Discourse Features Among Providers, Patients, and Companions and Their Effect on Outcomes of Dementia Diagnosis Disclosure. The fournals of Gerontology Series B Psychological Sciences and Social Sciences. 74, 756-763.

Xanthopoulou, P., Dooley, J., Meo, I., Bass, N. and Mccabe, R. (2019). Patient and companion concerns when receiving a dementia diagnosis: an observational study of dementia diagnosis feedback meetings. Ageing $\mathcal{G}$ Society, 39, 1782-1805.

Zaleta, A. K. and Carpenter, B. D. (2010). Patientcentered communication during the disclosure of a dementia diagnosis. American fournal of Alzheimers Disease and Other Dementias, 25, 513-520.

Zaleta, A. K. et al. (2012). Agreement on diagnosis among patients, companions, and professionals after a dementia evaluation. Alzheimer Disease \& Associated Disorders, 26, 232-237.

Zou, Y. et al. (2017). Caregivers' attitude toward disclosure of Alzheimer's disease diagnosis in Urban China. International Psychogeriatrics, 29, 1849-1855. 